\title{
Household Composition and the Response of Child Labor Supply to Product Market Integration: Evidence from Vietnam*
}

\author{
Eric V. Edmonds \\ Department of Economics \\ Dartmouth College and NBER
}

\begin{abstract}
Market integration raises the relative price of a community's export product. This study examines how the response of child labor supply to an increase in the relative price of a primary export product varies with a child's household composition. The specific context for this study is the liberalization of rice markets in Vietnam in the 1990s. Between 1993 and 1998, Vietnam lifted export restrictions on rice, allowing the domestic price to rise toward international levels, and eliminated internal restrictions on the flow of rice between regions of Vietnam. Thus, the relative price of rice increased overall in Vietnam, but the degree of price change varied across communities with the lifting of restrictions on internal flows. This study finds that the response of child labor supply to rice price increases is increasing the amount of time children work. Thus, household composition attributes that are associated with higher levels of child labor are also associated with larger declines in child labor with rice price increases. The results are consistent with girls particularly benefiting from product market integration, because they work more than boys do. These results suggest that economic factors associated with economic reform may attenuate differences in the activities of siblings that are typically associated with cultural traditions and norms.
\end{abstract}

JEL Codes: F15, J22, O15

Keywords: Trade Liberalization, Sibling Sex Composition, Birth Order, Child Labor, Gender

\footnotetext{
"I am grateful to Nayantara Mukerji, Harry Patrinos, Nina Pavcnik, Susan Razzaz, and Alexandra van Selm for their comments and to Savina Rizova for outstanding research assistance. This research was funded in part by the World Bank-Netherlands Partnership Program's Economic Policy and Gender Initiative. Contact Information: 6106 Rockefeller Hall, Department of Economics, Dartmouth College, Hanover NH 03755 USA, eedmonds@dartmouth.edu.
} 


\section{Introduction}

A key foundation of the so-called "Washington Consensus" is that the free flow of goods across national and international markets is critical to affect economic growth and improve household welfare. Generally speaking, there appears to be strong evidence that there are large gains from trade to be had by national and international market integration and that these gains from trade in some cases may be widely distributed across households (Collier and Dollar 2002). There is, however, little evidence on how the gains from national and market integration are distributed across children within the household. The aim of this study is to consider how the relationship between product market integration and child labor supply varies with household composition.

This study begins with a simple theoretical model that generates variation in the effect of market integration on child labor depending on the relative productivity of household members. Product market integration leads to relative price shifts for the liberalized commodity, and in the model where household members differ in their productivities in production, children who are relatively more productive experience larger changes in their labor supply with a change in relative prices. For example, a 25 year old is likely a more productive farm worker than is a 10 year old. As a result, equilibrium in household time allocation implies that the 10 year old ends up working relatively less and thereby will tend to experience a smaller decline in labor supply if market integration affects a decline in work among children. If instead of a 25 year old, the 10 year old worked with a 6 year old, then the 10 year old would work relatively more than when the 25 year old was present. Thus, when the effect of market integration is to diminish labor supply, there is scope for a greater effect on the labor supply of the 10 year old. In this way, the effect of market integration on child labor can depend on household composition. 
The empirical context of this paper is Vietnam's liberalization of its rice markets during the 1990s. Between 1993 and 1998, the real price of rice increased on average by almost 30\% relative to a consumer price index in Vietnam. Brandt and Benjamin (2004) show that international and national rice market integration are driving forces behind these rice price changes. In 1989, out of a concern for domestic food security, Vietnam imposed stringent export controls on its rice exports. Coupled with internal restrictions on the flow of rice across regions, these trade restrictions suppressed the domestic price of rice and lowered the relative incomes of rice producing households. However, from 1993 to 1998, the government gradually liberalized its export regime, increasing the quota from less than 1 million metric tons in 1992 to 4.5 million in 1998. The rise in international demand from the relaxation of the quota will put upward pressure on domestic prices of rice. In addition, the government lifted internal barriers to rice trade across regions within Vietnam in early 1997, beginning the integration of the national market for rice. National integration leads to relative price shifts with rice surplus areas experiencing larger price increases than rice deficit areas.

The empirical approach of this study is to relate regional and intertemporal variation in the relative price of rice to variation in child labor using rural, panel households from the Vietnam Living Standards Survey (VLSS). The VLSS is a multi-purpose household survey with community-level price surveys conducted in 1993 and 1998. This study captures sibling and household composition effects by allowing the effect of rice prices to vary with household and sibling composition. Of course, not all of the variation in rice prices observed in the data is attributable to national and international product market integration. However, to the extent that market integration leads to relative price variation, the results of this study suggest effects that could result from a market integration that induces a similar degree of price variation. In fact, 
there is a long tradition within international economics of examining how factors such as adult labor supply respond to relative price movements within a country (e.g. Leamer and Levinsohn 1995). The reason for this is summarized by Krugman (1991): "One of the best ways to understand how the international economy works is to start looking at what happens inside nations ... The data will be better and pose fewer problems of compatibility, and the underlying economic forces will be less distorted by government policies."

The next section of this paper outlines the theoretical model. Section 3 introduces the data, and section 4 develops the empirical specification. Section 5 presents the results. The empirical results of this study are largely consistent with the theoretical predictions of the model. Children that work more prior to liberalization experience large reductions in child labor supply with rice price increases. This appears to be because on average, increasing relative prices of rice are associated with declines in child labor and sibling differences in productivity amplify the effect of rice price increases for more productive children. Section 6 concludes.

\section{Theoretical Context}

This section develops a simple theoretical model that allows child labor to depend on household and sibling composition. It first considers how child labor supply responds to increases in rice prices (following Edmonds and Pavcnik 2003a), then how this response varies with household and sibling composition. The model in this section is built on two salient features of child labor and rice production. First, almost all child labor in Vietnam takes place inside the child's own household. Of children that participate in any economic activity in Vietnam in 1993, 97 percent do so only within their own household. Second, most households in Vietnam are exposed to rice price increases through both consumption (44 percent of food 
expenditure is on rice in 1993) and production (98 percent of all communities in Vietnam produced rice in 1993).

Households can produce two goods: rice ( $r$ ) and a nonagricultural good $(n)$. Define $p$ as the relative price of rice: $p=p_{r} / p_{n}$. The aim of this section is to show how the effect of changes in $p$ on child labor depends on household composition. Assume there are two types of workers in the household indexed 1 and 2. This section's discussion is framed as if both of these prospective workers are children although one worker could be viewed as a child and the other as an adult in order to extend this section's results to more the more general household composition question. Child 2's labor is a perfect substitute for $a$ units of labor type 1. That is, total child labor used in production is $L=L_{1}+a L_{2}$. When $a<1$, child 1 is more productive than child 2 .

There are a number of possible explanations for differences in productivity between children. Edmonds (2002) argues that differences in child labor associated with birth order can be explained by the fact that older children are better workers in most types of economic activities. Gender may also play a role in generating differences in productivity if there are certain agricultural tasks where males are more capable. Behrman and Taubman (1986) highlight a number of psycho-social reasons for differences between children associated with birth order. For example, older children grow up in a more adult environment. Thus, their behavior is closer to adult behavior, and they are more productive. Of course, it is not necessarily the case that older siblings are more productive. Later born children may have wealthier parents because of life-cycle earnings profiles. Coupled with the earnings of lower birth order children, this may improve the quality of human capital investments in higher birth order children (Willis and Parish 1993) and mean less child labor for younger children (Emerson and Portela 2002). Ejrnæs and Pörtner (2000) argue that the presence of higher birth order 
children signals that the latent ability of lower birth order children is low. Their idea is that parents only decide to have additional children if their first draw is less able than expected. Birdsall (1991) argues that mother's time is a critical input into the productivity of children and that a mother has the least time to invest in middle children. Hence, ex-ante the link between birth order and productivity is not clear. However, in the empirical work below, older children appear more productive. Hence, the discussion in this section follows with the assumption that older children are more productive than their younger co-residents.

Household income depends on its use of land $K$ and labor $L$ as well as the relative price of rice $p$. Each household is treated as a small enterprise that employs both factors of production and trades neither. Land is assigned to the household, so the household's problem is to choose how much of each type of labor it uses. Aggregate household income is given by the profit function: $I \equiv G(p, K, L)$ with $\mathrm{G}_{\mathrm{p}}>0, \mathrm{G}_{\mathrm{k}}>0, \mathrm{G}_{\mathrm{L}}>0, \mathrm{G}_{\mathrm{pp}}>0, \mathrm{G}_{\mathrm{kk}}<0$ and $\mathrm{G}_{\mathrm{LL}}<0$. The main focus of the empirical work is on how household or sibling composition interacts with rice prices in affecting child labor supply. Thus, in the discussion of this section, adult labor supply is implicit in the profit function, and the household's problem is to decide how much of child 1 and child 2's labor to use. Nevertheless, this section's theoretical results can be applied to the household composition empirical results if labor types are reinterpreted as referring to child and non-child labor.

The profit function defines the household's demand for each type of child labor. Child 1 receives a (shadow) wage that is the value of its marginal product in the household profit function: $w_{1} \equiv G_{L}\left(p, K, L_{1}+a L_{2}\right)$. This is the inverse demand function for child 1's labor in the household's production problem. Similarly, define $w_{2} \equiv a G_{L}\left(p, K, L_{1}+a L_{2}\right)$. 
Household welfare depends on household consumption of rice and non-agricultural goods as well as the amount that each child works: $\left\{L_{1}, L_{2}\right\}$. Child labor is a bad in household preferences. Let household preferences with respect to the labor supply of each child, be represented by the indirect utility function:

(1) $\quad v\left(p, I, L_{1}, L_{2}\right)=u\left(\frac{I}{\beta(p)}\right)-h_{1}\left(L_{1}\right)-h_{2}\left(L_{2}\right)$

where $\beta(p)$ is the price index, $\mathrm{u}$ is increasing and concave (i.e. $\mathrm{u}^{\prime}>0, \mathrm{u}^{\prime \prime}<0$ ), and $h_{i}$ is increasing and convex (i.e. $\mathrm{h}^{\prime}>0, \mathrm{~h}^{\prime \prime}>0$ ). For notational simplicity, define $R \equiv \frac{I}{\beta(p)}$. This set-up in (1) assumes separability between consumption and child labor, separability between the disutility of having each child work, and homotheticity of preferences over consumption goods.

Allowing $h$ to vary across children permits the household to feel differently about the labor supply of child 1 and child 2. When a child is not working, it may be enjoying leisure, play, or perhaps attending school. Hence, $h$ embodies how the household values the return to any of these activities. $h$ may differ across children because of parental preferences over children, differences in the actual or perceived returns to schooling, social customs, etc. This may be particularly important in understanding gender differences in child labor. Parish and Willis (1993) emphasize social norms as an important reason for why eldest girls tend to support the family more than other siblings in Taiwan. Emerson and Portela (2002) find a similar result in Brazil. These eldest girls would have a different $h$ in this model.

The child labor supply function for each child (i) follows out of the household's

optimization problem: $\frac{\partial v}{\partial L_{i}}=u^{\prime}(R) \frac{\partial R}{\partial L_{i}}-h_{i}^{\prime}\left(L_{i}\right)=0$. Because $\frac{\partial R}{\partial L_{i}}=\frac{1}{\beta(p)} \frac{\partial G}{\partial L_{i}} \equiv \frac{w_{i}}{\beta(p)}$, the 
household's labor supply function for each type of child labor is defined by $w_{i}=\frac{h_{i}^{\prime}\left(L_{i}\right) \beta(p)}{u^{\prime}(R)}$.

Coupled with the equilibrium in labor demand ( $\left.a w_{1}=w_{2}\right)$, these labor supply functions imply that the negative of the marginal rate of substitution between the labor child one and two equals the inverse of $a$ or equivalently:

(2) $\quad a h_{1}^{\prime}\left(L_{1}\right)=h_{2}^{\prime}\left(L_{2}\right)$.

Because of the assumptions on $\mathrm{h}$, the more productive child 1 works more than the less productive child 2. The solution to the household's problem is to equate child labor supply with child labor demand. Thus, equilibrium is defined by:

(3) $\frac{\partial G}{\partial L_{i}}=\frac{h_{i}^{\prime}\left(L_{i}\right) \beta(p)}{u^{\prime}(R)}$

and is an implicit function of market prices, family resources, and tastes.

To consider how a movement in the relative price of rice affects the labor supply of child $i$, totally differentiate (3):

$$
\begin{aligned}
& \frac{h_{1}^{\prime \prime}\left(L_{1}\right) \beta(p)}{u^{\prime}(R)} d L_{1}-\frac{h_{1}^{\prime}\left(L_{1}\right) \beta(p) u^{\prime \prime}(R)}{\left[u^{\prime}(R)\right]^{2}} \frac{\partial R}{\partial L_{1}} d L_{1}-\frac{h_{1}^{\prime}\left(L_{1}\right) \beta(p) u^{\prime \prime}(R)}{\left[u^{\prime}(R)\right]^{2}} \frac{\partial R}{\partial L_{2}} d L_{2} \\
& +\frac{h_{1}^{\prime}\left(L_{1}\right) \beta^{\prime}(p)}{u^{\prime}(R)} d p-\frac{h_{1}^{\prime}\left(L_{1}\right) \beta(p) u^{\prime \prime}(R)}{\left[u^{\prime}(R)\right]^{2}} \frac{\partial R}{\partial p} d p=G_{L L} d L_{1}+a G_{L L} d L_{2}+G_{L P} d p
\end{aligned}
$$

The household's equilibrium relationship between the labor supply of each child , eq. (2), determines how the labor supply of child 1 changes with a change in the labor supply of child 2 . Totally differentiating (2) yields:

(4) $\quad d L_{2}=a \frac{h_{1} "\left(L_{1}\right)}{h_{2} "\left(L_{2}\right)} d L_{1}$ 
That is, how the labor supply of child 2 moves with changes in the labor supply of child 1 depends on their relative productivities and the household's preferences over the labor supply of each child. Plugging in for (4)and $\frac{\partial R}{\partial L_{i}}$, plus rearranging, yields:

$$
\begin{aligned}
& \frac{h_{1}{ }^{\prime \prime}\left(L_{1}\right) \beta(p)}{u^{\prime}(R)} d L_{1}-\frac{h_{1}{ }^{\prime}\left(L_{1}\right) u "(R)}{\left[u^{\prime}(R)\right]^{2}} \frac{\partial G}{\partial L} d L_{1}-\frac{a^{2} h_{1}{ }^{\prime}\left(L_{1}\right) u{ }^{\prime \prime}(R)}{\left[u^{\prime}(R)\right]^{2}} \frac{h_{1}{ }^{\prime \prime}\left(L_{1}\right)}{h_{2}{ }^{\prime \prime}\left(L_{2}\right)} \frac{\partial G}{\partial L} d L_{1}-G_{L L} d L_{1}-a^{2} G_{L L} \frac{h_{1}{ }^{\prime \prime}\left(L_{1}\right)}{h_{2}{ }^{\prime \prime}\left(L_{2}\right)} d L_{1} \\
& =G_{L P} d p-\frac{h_{1}{ }^{\prime}\left(L_{1}\right) \beta^{\prime}(p)}{u^{\prime}(R)} d p+\frac{h_{1}^{\prime}\left(L_{1}\right) \beta(p) u^{\prime \prime}(R)}{\left[u^{\prime}(R)\right]^{2}} \frac{\partial R}{\partial p} d p
\end{aligned}
$$

Define: $\Delta_{1}=\frac{h_{1}{ }^{\prime \prime}\left(L_{1}\right) \beta(p)}{u^{\prime}(R)}-\left(\frac{h_{1}{ }^{\prime}\left(L_{1}\right) u \text { " }(R)}{\left[u^{\prime}(R)\right]^{2}} \frac{\partial G}{\partial L}+G_{L L}\right)\left(1+a^{2} \frac{h_{1}{ }^{\prime \prime}\left(L_{1}\right)}{h_{2}{ }^{\prime \prime}\left(L_{2}\right)}\right) \cdot \Delta_{1}$ is positive by

assumption $\left(h_{1}{ }^{\prime}>0, h_{1}{ }^{\prime \prime}>0, u^{\prime}>0, u^{\prime \prime}>0, G_{L}>0, G_{L L}<0\right)$. Note $\frac{\partial R}{\partial p}=\frac{\beta G_{p}-G \beta^{\prime}}{\beta^{2}}=\frac{G_{p}}{\beta}-\frac{G \beta^{\prime}}{\beta} \frac{1}{\beta}$. The derivative of the profit function with respect to the price of rice is just output, $G_{p}=y_{s}$. Roy's identity implies that $\frac{G \beta^{\prime}}{\beta}=y_{d}$. Thus, $\frac{\partial R}{\partial p}=\frac{1}{\beta}\left(y^{s}-y^{d}\right)=-\frac{1}{\beta} m$ where $m \equiv\left(y_{d}-y_{s}\right)$ is the household's net consumption of rice. Plugging in yields an expression for how child labor responds to a change in the relative price of rice:

$$
d L_{1}=\frac{1}{\Delta_{1}}\left[\left(G_{L P}-\frac{h_{1}^{\prime}\left(L_{1}\right) \beta^{\prime}(p)}{u^{\prime}(R)}\right)-\left(\frac{h_{1}^{\prime}\left(L_{1}\right) u^{\prime \prime}(R)}{\left[u^{\prime}(R)\right]^{2}} m\right)\right] d p
$$

This emphasizes three ways in which child labor may decline with an increase in the relative price of rice. The first term of (5) denotes the pure substitution effect on the production side toward or away from child labor. The pure substitution effect in production is positive if rice production is child labor intensive. That is, as rice prices increase, children may be drawn to 
work more in rice production. However, rice production might not be child labor intensive relative to household production. In this case, increases in rice prices may draw other workers into rice production, causing a decline in child work in rice production. Thus, the pure substitution effect in production may be positive or negative depending on the relative intensity of child labor in rice production. The second term is the pure substitution effect in consumption away from rice toward child leisure. When rice prices increase, the price index $\beta(p)$ increases. Thus, $h^{\prime} \beta^{\prime} / u^{\prime}(R)$ is positive. Hence, as a result of increasing rice prices, equilibrium in the household causes the household to consume more of the relatively cheaper child leisure. The last term is the terms of trade or net income effect for the household. If the household is a net importer of rice $(m>0)$, then this term unambiguously leads to an increase in child labor. If the household is a net exporter of rice (i.e. $m<0$ ), then the net income effect of an increase in the price of rice is to reduce child labor. Overall, then, the net effect of a rice market liberalization induced increase in the relative price of rice is ambiguous.

In order to understand how the effect of rice prices varies with sibling composition, first consider the case where there is no sibling $(a=0) . \quad \Delta_{1}$ is smaller in the absence of siblings. Hence, the labor supply of the child (for a given marginal disutility of labor) is more responsive to price changes in the absence of siblings. The intuition behind this is that the benefits or costs of rice price increases are spread over children. Without siblings, there are no children to share the benefits or spread the costs of rice price increases with. Of course, the marginal disutility of labor may be different in the presence of siblings so diminished sensitivity to price changes in the presence of siblings is not a general result.

In order to understand how the effect of rice prices on child labor supply depends on the relative productivity of siblings, it is helpful to consider how the response of child 1's labor 
supply to a price change varies with a small change in $a$. To consider this, take the partial derivative of $d L_{1} / d p$ with respect to $a$ :

$$
\frac{\partial^{d L_{1}} / d p}{\partial a}=\frac{2 a}{\Delta_{1}} \frac{h_{1}{ }^{\prime \prime}\left(L_{1}\right)}{h_{2}{ }^{\prime \prime}\left(L_{2}\right)}\left(\frac{h_{1}{ }^{\prime}\left(L_{1}\right) u^{\prime \prime}(R)}{\left[u^{\prime}(R)\right]^{2}} \frac{\partial G}{\partial L}+G_{L L}\right) \frac{d L_{1}}{d p}
$$

The term in parenthesis is negative, so the effect of a change in $a$ on how rice prices affect child labor depends on the sign of the net effect of rice prices on child labor. If rice prices increase child labor supply, then an improvement in the productivity of child 2 mitigates the amount that the relatively productive child 1's labor supply has to increase. This is because the improvement in child 2's productivity leads child 2 to bear more of the necessary increase in work while incurring less disutility for the household (it costs child 2 less actual labor units). If rice price increases decrease child labor, then an increase in the productivity of a sibling means that child 1's decline in child labor will be relatively less, because child 1 contributes less labor initially.

The discussion in this section has been focused on the case where both workers are children. The basic result for how household composition induces variation in how child labor responds to price changes is that when a child is relatively more productive, the child works more, and thereby can experience larger declines in child labor if price increase lead to a decline in child labor. This result generalizes to the case of one adult and one child instead of the two child workers considered explicitly in this section so long that the adult and child labor are perfect substitutes in production after an equivalence adjustment. For example, the results of this section suggest if an older adult is present instead of a younger sibling, then the child works less before the price increase and thereby experiences a smaller decline in work with the increase in prices. How realistic is this assumption that that adult and child labor are perfect substitutes after an equivalence adjustment? This assumption is commonplace in the theoretical literature on 
child labor (e.g. Basu and Van 1998), and there is surprisingly little evidence against the assumption (see Levison and others (1998) for an example and discussion). Thus, the discussion in this section is applicable to the more general household composition case in addition to the sibling comparison case that is considered explicitly.

\section{Data Description}

The relationship between product prices in the rice sector and the economic activities of household members is investigated using two rounds of the Vietnam Living Standards Survey (VLSS) that span the period of rice market liberalizations. The first round of the VLSS was conducted between September 1992 and October 1993. The second round of the VLSS revisited 147 communes from the first round between December 1997 and December 1998. This study focuses on households in the 115 revisited rural communes and is not limited to panel households that are interviewed in both rounds of the survey. The sample is limited to rural households, because rural households have the potential to be exposed to price changes on both the consumption and the production side. Hence, they should display all of the mechanisms discussed in the previous section. The household survey includes questions on household composition, the labor activities of adults and children, education, expenditure, land holdings, and agricultural activities. The household survey is accompanied by a community questionnaire that includes detailed price information.

\subsection{Rice Prices}

This paper relates changes in the price of rice to changes in the economic activities children, allowing the association between rice price changes and child labor to vary with sibling and household composition. Thus an overview of the observed rice price changes is important to understand identification. The price of rice is deflated with the monthly consumer price index so 
that all prices are in 1998 (January) Dong. The price deflator does not vary by region. Thus, the variation in real rice prices observed in the data stems from movements in rice prices rather than the price index. The mean rice price in 1993 was 2,600 dong per kilogram of ordinary rice (author's calculation from the 1992/93 Vietnam Living Standards Survey). One U.S. dollar corresponds to approximately 14,000 Dong in 1998, so the price of rice in 1993 is approximately 19 cents per kilogram. The average domestic price of ordinary rice increases by $28 \%$ relative to the rise in the consumer price index between 1993 and 1998 to approximately 24 cents per kilogram (author's calculation using the 1997/98 Vietnam Living Standards Survey).

Benjamin and Brandt (2004) describe the sources of rice price variation in greater detail. They highlight two reasons for why rice prices rise. First, the increase in the overall level of prices may be attributable to the decline in the rice export quota that took place during the 1990s. Out of a concern for domestic food security, Vietnam implemented a rice export quota in the late 1980s in order to suppress the domestic price of rice. During the time of the data, Vietnam gradually liberalized the quota so that by 1997, it was no longer binding. The lifting of the quota may lead to asymmetric price changes if communities vary in their exposure to the effects of lifting the quota. This may occur if there are important transport costs that are a function of the value of the rice being exported out of the exporting community or if the transport costs are on the quantity of rice exported which is in turn associated with the baseline price.

The second major source of rice price variation across communities is Vietnam's lifting of restrictions on the flow of rice across communities in 1997. Prior to 1997, communities that would become rice exporters in 1998 received relatively lower prices than rice importers. The easing of restrictions on the flow of rice across communities, then allowed price changes that are largest in the net exporting regions. Overall, though, there does not appear to be national 
convergence, so both the integration of domestic markets and the rice export quota are likely responsible for the price changes that are exploited in this study.

\subsection{Household and Sibling Composition}

The aim of this empirical work is to relate rice prices movements to changes in child labor supply allowing the effects to vary based on household and sibling composition. In the analysis, this study focuses on households with children 6-15 in the 115 rural communes that are visited in both rounds of the VLSS. Age 6 is chosen as a lower bound, because the VLSS does not collect data on the activities of children below 6. 15 is the upper bound following convention on many international treaties on child labor. This restriction leads to 2,255 households in 1993 and 2,375 households in 1998. The increase in sample size in part reflects a decision on the part of the General Statistical Office of Vietnam to increase the sample size between rounds of the VLSS as well as a rise in the number of children ages 6-15. Table 1 summarizes household and sibling composition in 1993 and 1998 for the nationally representative VLSS samples and the restricted sample of households with children 6-15 in rural panel communes used in the analysis.

Unsurprisingly, households with children tend to be larger than average. Likewise rural households have more children than do urban households. Thus, household size is approximately half a person larger in the study sample than in the nationally representative dataset.

Overall household size is smaller in 1998 than in 1993. This is true in the nationally representative sample and in the selected sample of rural households with children in panel communes. The decline in household size between years is about half a person. Most of the decline is in children under 5. The onset of economic reform in Vietnam in 1986 is associated with a large decline in fertility that is associated with a significant increase in the average age of 
the population. There appears to be a second, even larger decline in fertility accompanying economic reforms in the mid 1990s.

The bottom panel of table 1 summarizes certain household composition averages for children 6-15 that can differ across children within the same household (the top panel does not). Most children have both parents present, although fathers are slightly more likely to be absent than are mothers. The probability that a child resides with a parent (individually or jointly) increases between 1993 and 1998, but these changes are not statistically significant.

A sibling in this study is defined as a co-resident individual of any age that shares at least one parent in common with the child. In counting siblings, the reference child is not counted. Thus, the average child 6-15 in 1993 has 3.3 other people living in the same household with at least one parent in common. The average child 6-15 in 1998 has 2.7 co-residents that share a parent. The row "fraction brothers" displays the fraction of all siblings that are male. The sex distribution of siblings is fairly equal. The fraction of siblings that are male increases slightly in 1998, but the change is not statistically significant. The row "fraction younger" contains the fraction of siblings that are younger than the reference child. For the children 6-15 examined in this study, their average sibling is older, and the share of siblings that are older increases between 1993 and 1998. This rise in the share of siblings that are older is to be expected given the decline in fertility that occurs in Vietnam between 1993 and 1998.

An obvious concern in this study is that household composition may also adjust in reaction to price changes. Edmonds, Mammen, and Miller (2003) document changes in household composition associated with changes in household income in South Africa. Shifts in household composition could affect child labor supply in ways that do not follow directly from the mechanisms through which rice price increases affect child labor supply that section 2 
describe. For example, rice price increases may cause large landholding households to desire more labor. In the presence of labor market imperfections, increased labor may spur the household to import more labor directly into the household. In turn, changes in household labor could affect the allocation of child time. This type of mechanism for changes in child labor supply is not captured in the theoretical framework of section 2. However, it may be an important part of the reduced form effect of rice price changes. Hence, the empirical work in the next section will not attempt to separately identify the various income and substation effects described in the previous section. Rather, they serve as motivation for why rice price increases might affect child labor. Shifts in household composition may be an additional mechanism.

\subsection{Child Labor}

In general, there are large changes in child labor occurring in Vietnam in the 1990s (Edmonds and Turk 2004). Table 2 summarizes by gender and year the changes in child labor that occur in the sample of rural households in communes that are visited in both rounds of the VLSS. Throughout this study, the focus is on children 6-15. The top panel of table 2 contains participation rates in various activities in the last 7 days. Wage work consists of work for pay (in cash or in kind) outside of the child's household in agricultural or non-agricultural activities. Within the household, the VLSS collects data on participation in the family's farming activities (labeled "agriculture"), the family's non-farm home enterprise, and household production. Participation in household production is asked in a single question that defines household production as domestic duties, home repair and household maintenance, time spent working on agricultural tools, caring for animals, fetching water, and collecting firewood. Participation in each category of activity (wage work, own farm agriculture, home enterprise, household production) is asked directly in the questionnaires and the questions in the survey instrument are 
identical in both rounds of the VLSS. Moreover, these categories are not mutually exclusive. A child may respond that she participates in all of them as well as none of them.

Three constructed variables in the top panel of table 2 measure child participation in a combination of these activities. Market work indicates participation in wage work or work inside the household in agriculture or a home enterprise. Any work indicates participation in market work or household production. Much of this study's analysis focuses on the participation measure labeled "active." A child is active if she participates in market work of spends 7 or more hours in the last 7 days in household production.

This participation measure "active" corresponds to the definition of child labor employed by the International Labor Organization in many of its SIMPOC country studies. This study uses the word "active" instead of child labor in order to avoid argument over how to define child labor. Instead "child labor" is understood to refer broadly to the set of activities (other than schooling) described in table 2. Many studies of the activities of children tend to focus on market work alone (for examples, see the studies collected in Grootaert and Patrinos 1999). In the present context, some of the aspects of the household production question fall within the ILO's official definition of "economically active", so the household production data should not neglected even if domestic duties were not of substantive interest. Moreover, the consideration of time in household production overcomes three main conceptual problems that arise in studies that from failing to consider the activities performed by children in the production of nontradable goods (home production). First, when a child works outside of its household as a paid domestic servant or a slave that child is classified as a child laborer under the most stringent of definitions. Reclassifying the child's production activities as something other than work if the child's employer changes (even if it changes to a parent) seems arbitrary. Second, treating the 
production of nontradables as "not-working" makes it difficult to interpret the meaning of the state of "not working." For example, if home production is ignored in the definition of child labor, a child that stops limited work in a family business to take over extensive household responsibilities (say, because of the absence of a parent) would appear to stop working. Third, an assertion that child participation in the production of nontradables is not an economic phenomenon (or of economic interest) implies that including home production in a definition of child labor should attenuate any findings. To the extent that participation in the production of nontradables varies with changes in the relative price of a market good, it clearly is of economic importance.

The bottom panel of table 2 summarizes hours worked per week in wage work and within household work. The two constructed hours worked measures are market work (the sum of wage work, own farm work, and household enterprise work) and total hours (the sum of market work and work in household production). While the participation questions are identical in both rounds of the VLSS, there is dramatic change in the way that information on hours in own-farm work is collected. Edmonds and Pavcnik (2003b) discuss how this change in questionnaire may introduce bias into the discussion of how rice price changes are related to hours worked in agriculture, market work, and total hours. Thus, the focus of the analysis in this paper is largely on participation. Hours worked results will be presented in tandem with the caveat that there is good reason to believe that there may be considerable bias in changes in hours worked in agriculture.

Two aspects of child labor in Vietnam in the 1990s are evident in table 2. First, girls tend to work more than boys. Girls have higher participation rates in each category of work in both rounds of the VLSS with the exception of non-agricultural wage work in 1998 and home 
enterprise work in 1998. Most of the gender differences in participation are small in size and statistically insignificant. The one category where the difference in participation is large and statistically significant is work in household production. This translates into significant differences in participation in work within the household, any work, active, and active without school. Similarly, average hours worked in household production are also different between genders. Girls work on average 2.9 more hours per week in 1993 and 1.8 more hours per week in 1998 in household production. Coupled with the slightly higher hours worked per week by girls in activities other than wage work (where hours worked are equal), girls end up working a total of 3.4 more hours per week in 1993 and 2.2 more hours per week in 1998.

Second, both boys and girls experience large declines in child labor between 1993 and 1998. Participation in every type of work declines between 1993 and 1998 with the exception of participation in household production which increases slightly for boys and does not decline for girls. Aside from hours worked in nonagricultural wage work for boys which does not change, average hours worked declines in every type of work in table 2. The magnitudes of the changes in participation rates for each category of work are roughly similar for boys and girls. Girls experience a slightly larger decline in own-farm work and home enterprise work, but these differences are not statistically significant. However, the consequence of slightly larger declines in own-farm and home enterprise work for girls is that gender differences participation rates are generally smaller in 1998 than in 1993. Gender differences in hours work also converge, because girls experience similar or slightly larger (but never statistically significant) changes in hours worked than experienced by boys. In percentage terms, both boys and girls experience a 7 percent decline in participation in work within the household and a 20 percent decline in children who are "active". Total hours worked decline for both genders by approximately 25 percent. 
Table 3 previews the relationship between household composition and children being active. Children 6-15 in 1993 and 1998 are pooled together in table 3. Column 1 summarizes the household composition variables described in the context of table 1 for children who are active and column 2 provides household composition summary statistics for children who are not active. The children 6-15 that are analyzed in this study are included in household composition measures such as the number of persons 6-15 in the households although they are not included in sibling counts (as in Table 1). Some of the relationships between child labor and household composition evident in table 3 are important in the discussion below. First, children that work tend to have fewer young adults (16 to 24) and prime-age adults (25-64) although these differences are small and not statistically significant. Second, working children tend to have more co-resident siblings. These additional siblings are disproportionately younger, especially younger brothers. The results below indicate that child labor increases in the number of younger siblings, especially if those siblings are brothers. The effect of rice prices on child labor then varies with this attributes. Adding younger siblings increases the decline in child labor associated with rice price increases, but if these younger siblings are brothers more than sisters, the decline in child labor with rice price increases is mitigated.

\section{Identification of Household Composition Effects}

The empirical approach of this paper is to relate these changes in child labor to changes in rice prices, allowing the coefficient on rice prices to vary with household and sibling composition. This study does not aim to explain the source of variation in rice price increases across communities. There are any number of reasons aside from market integration for relative price shifts although Benjamin and Brandt (2004) argue that the easing of the rice export quota and the lifting of internal restrictions on the flow of rice across regions are the primary drivers 
behind rice price movements. This study's purpose is to consider how relative price movements affect changes in child labor supply, because market integration leads to relative price shifts. Thus, even if market integration is not behind the observed price movements, the link between price movements and child labor supply can still inform about the effect of market integration on child labor supply.

However, this approach of linking child labor supply to price variation raises several concerns. Namely, any number of local economic factors may be associated with both rice price movements and child labor supply movements but have nothing to do with the causal effect of rice price changes on child labor supply. This section begins with a description of some of the more problematic confounding factors, describes how the empirical framework attempts to control for them, and ends with a discussion of some of the remaining problems that the empirical work cannot address. This discussion is largely based on Edmonds and Pavcnik (2003c). That study is devoted to the question of whether the relationship between price movements and child labor supply is driven by omitted factors correlated with price movements and child labor that have nothing to do with the causal effect of rice price movements on child labor. They find that the relationship between changes in rice prices and child labor supply is extremely robust. Even when they control for observable factors that can account for over 90 percent of the variation in rice prices, they find a response of child labor supply to price movements that is nearly identical to that observed without controlling for factors that might be associated with rice price movements.

\subsection{Likely Sources of Spurious Correlation}

Sources of spurious correlation between price movements and child labor supply can be grouped into two general categories: time invariant and time varying attributes. 
The most obvious time invariant attribute is that rice prices in part reflect characteristics of a local community. Some communities may have a large number of consumers relative to producers. In autarky, that community will have high rice prices. Alternatively, a community may have land that is suited towards rice production. In that case, supply may large relative to demand and autarky prices will be low. Thus, with integration, price movements may be correlated with latent supply and demand factors and it is not difficult to imagine why these supply and demand factors may also be correlated with child labor supply. Any number of other community attributes may be important to both rice prices and child labor. For example, the economic activities of households and rice prices might vary across communes because communes differ in the availability of schooling, labor market conditions, land and resource endowments, and integration into the Vietnamese economy. Together, these unobserved commune characteristics would bias estimates of the effect of rice prices on participation in economic activities. However, the panel nature of the data permits the inclusion of commune fixed effects in all regressions to control for time-invariant commune characteristics. Within communities, there may be unobserved heterogeneity in households that is correlated with both rice prices and labor market participation. However, since the effect of rice prices on child labor is identified with community*time variation in rice prices, household heterogeneity is unlikely to generate bias.

Time varying community attributes that may generate a spurious correlation between rice price movements and child labor are somewhat more difficult to deal with. First, unobserved economy-wide time shocks that could affect the probability a person works and rice prices are controlled for with a year indicator that is one if the survey year is 1997/98 (1992/93 is the omitted year). Second, rice price changes vary differentially across Vietnamese regions (see 
Benjamin and Brandt 2004). At the same time, different regions might have implemented differential policy changes and infrastructure improvements during the sample. Or, labor mobility across regions might be limited, which could lead to variation in the changes in the returns to schooling across regions. These unobserved region-specific time-varying shocks could result in spurious correlation between rice prices and economic activities. These concerns however can be addressed by interacting each region indicator with a year indicator. ${ }^{1}$ Third, Vietnamese communes differ in their accessibility. If more accessible communes are better integrated into international and national rice markets, these communes might undergo bigger rice price changes. Similarly, accessibility might be associated with a range of time-varying factors affecting labor supply. The VLSS provides information on whether regular transportation is provided to a commune and whether the road to commune is paved. Based on this information, two indicator variables for a communes' accessibility are constructed and interacted with the year indicator. Inclusion of these two interactions in the empirical framework allows for a different change in economic activities in accessible communes. Fourth, communities are interviewed at different times of the year in each round of the survey. This might generate a spurious correlation between changes in child labor and rice prices due to seasonality. For example, rice prices may be low in harvest season and demand for child labor high. Rice prices may be high in off-season and demand for child labor low. Thus, a regression of rice prices on child labor would merely capture the fact that different communities are interviewed at different times. In the empirical work, this can be controlled for by the inclusion of season indicators, an indicator for whether the interview took place at a rice harvest, and an indicator for whether an interview took place at rice planting time control for seasonal variation.

\subsection{Empirical Framework}

\footnotetext{
${ }^{1}$ There are 4 to 35 sampled communes per region (the mean and the median are both 25 communes per region).
} 
The empirical approach follows directly out of these concerns. For a child $j$ in commune $i$ at time $t$, the following is estimated:

$$
y_{i j t}=\beta_{0}+\beta_{1} R P_{i t}+\beta_{2} R P_{i t} * H_{j t}+\varphi_{1} X_{j t}+\varphi_{2} H_{j t}+\alpha_{1} C_{i t}+\alpha_{2} T_{t}+\alpha_{3} A_{i} * T_{t}+\lambda_{i}+\varepsilon_{i j t} .
$$

$y_{i j t}$ is an indicator for whether child $j$ works at time $t$. Though the focus of the results is on participation rather than hours because of the data problems discussed above, $y_{i j t}$ is at times hours worked in various types of work. When $y_{i j t}$ refers to a participation variable, (6) is a linear probability model. $R P_{i t}$ is the natural logarithm of the real price of a kilogram of ordinary rice, and $R P_{i t} * H_{j t}$ is the interaction of the natural logarithm of the rice price with one of the various measures of sibling or household composition that are considered below. All regressions also control for differences in child labor supply associated with the various household and sibling composition measures. Thus, the effect on child labor supply of various household and sibling measures is $\beta_{2} R P_{i t}+\varphi_{2}$ and thus depends on the rice price in the community. By and large, the discussion below focuses on $\beta_{2}$, or how the effect of rice prices on child labor various with household and sibling composition rather than on the effect of changes in household composition on child labor.

(6) also includes several controls for factors associated with rice price changes and child labor. The vector $X_{j t}$ captures personal characteristics. Labor supply might differ across people because of differences in gender and age. Gender and age differences are captured using a third order polynomial in person's age, a gender (male) indicator, and an interaction of the gender effect with all terms of the age polynomial. $T_{t}$ is a year indicator, $\lambda_{i}$ is a commune fixed effect that controls for time-invariant community attributes, and $C_{i t}$ is a vector of time-varying community characteristics such as season of interview and whether rice production or planting is 
on-going at the time of the interview. $A_{i}$ is a vector of time-invariant community characteristics such as region indicators and commune accessibility indicators interacted with time to allow different time trends in labor supply associated with these community traits. Commune accessibility and region indicators cannot be included without year interactions, because the commune fixed effect already captures time-invariant commune characteristics such as the region in which the commune is located and commune's accessibility. In all regressions, the standard errors are corrected for heteroskedasticity and clustering at the level of variation of rice prices (psu/survey round).

\subsection{Remaining Conceptual Issues}

There are four remaining conceptual issues not addressed in the empirical framework that should be raised. The first three issues (migration, attrition, and types of child labor) are dataset specific and the fourth issue (endogenous household composition) is more conceptual.

First, the panel in the VLSS is not an individual panel. No effort is made to track individuals that move out of the household. The out migration of children will be missed in the dataset. This might raise a problem in the analysis below if children move in or out of households because of rice price movements. Edmonds and Turk (2004) consider how large a problem children missing for work might be in VLSS panel households. They find that at most 36 out of 6003 children who are 0-10 in the first round of the VLSS may be missing from the second round of the VLSS for work reasons. Thus, at least for children, missed changes in labor supply owing to migration are not likely to significantly distort the results below.

Second, the VLSS does not track households that move. Thus, if rice price increases affect household movements and thereby child labor, this type of dynamic is missed entirely. Mobility restrictions in Vietnam are rather severe, so this data limitation is not as much of a 
problem as one might fear. Moreover, the present study is not based on panel households but rather panel communes. Within a commune, the set of households is random. Hence, individual household attrition is not a concern, but changes through time in the types of households within a community would be a concern. A similar concern is that a household survey in general does not observe homeless individuals and street children. Thus, the data will miss any effect of rice price movements on homelessness or the incidence of street children.

Third, many forms of child labor are not captured by the VLSS. In the extreme, some of the most exploitative forms of child labor, such as child prostitution, are likely to be hidden because they are illegal. One could imagine that improvements in household income may increase demand for some illegal activities but decrease the household's willingness to supply children for these activities. Thus, there is scope for a link between rice price increases and the worst forms of child labor although it is not clear what direction the link goes. Even within activities that are captured in the VLSS, there is no information on working conditions. This may be substantive if, for example, the declines in child labor that come with rice price increases result from households substituting mechanical or chemical inputs for child time. A child may be better off working 20 hours a week hand-weeding than 5 hours a week spreading pesticides and fertilizers without protection. Thus, the conditions of working children could deteriorate as a result of rice price increases in tandem with declines in child labor. There is simply no available data to evaluate whether this happens.

Fourth, endogenous household composition may substantively affect the conclusions of this study. As discussed in the previous section, if one could assume that household composition was fixed and exogenous to price changes, then it would be possible to separately identify income and substitution effects with the available data. However, this is a strong assumption. 
As such, the data can only inform about reduced form effects of rice prices on child labor. A second implication of endogenous household composition is that conditioning on control variables such as the number of persons of a certain age in the household may capture some of the effect of rice prices on child labor. That is, say rice prices increases cause households to increase the number of young adults in the household. Moreover, assume that increasing the number of young adults in the household lowers child labor, because young adults are better workers than children. Then, conditioning on the number of young adults in the household actually captures some of the way that rice prices affect child labor supply, attenuating the estimated effect of rice prices in the data.

While this scenario suggests an attenuation of the observed effects of rice prices, endogenous household composition could also inflate estimates of the effect of rice price increases. For example, say that rice price increases enable households to overcome liquidity constraints and send children away to better schools. Then, the remaining children may be the less productive children if productivity in school and productivity on the farm are correlated. Less productive children may be less likely to work. Thus, there will appear to be a decline in child labor even though the observed children have not changed their labor supply. Moreover, the interactions of household composition with rice prices may appear significant if households adjust their composition by bringing in other workers to substitute for the children sent away to school.

It is difficult to measure how important these shifts in household composition are in the data, but the data do not support the assertion that there are large, substantive shifts in household composition. First, , in table 1, it is evident that generally speaking, aside from the decline in young children, there are not large changes in household composition. This is especially true for 
the adult population. Second, most of the latent factors associated with child labor and changes in household composition should be captured by controlling for household composition. The set of cases where changes in household composition associated with changes in child labor vary with rice prices continuously is much smaller. In addition, these shifts in household composition are likely of second order to the large income and substitution effects associated with rice price increases observed in Edmonds and Pavcnik (2003a). Even in cases where households receive dramatic increases in income, changes in household composition are relatively minor and require extremely large data sets to identify (see Edmonds, Mammen, and Miller (2002) for discussion). In the present case, regressions of all of the various household composition measures used in this study on rice prices and the other controls described in (6) reject the hypothesis that there are changes in household composition with rice price increases in every case except for the number of persons in the household above the age of 65 . Thus, endogenous household composition represents a potential problem in interpreting the results of the next section, but the available evidence does not suggest this problem is of first-order concern.

\section{Results}

This section examines in the VLSS data how the relationship between child labor and rice prices varies with household and sibling composition. A number of studies have examined the relationship between various measures of child labor and rice price changes in this dataset (e.g. Edmonds and Pavcnik 2003a, 2003b, and 2003c), so the focus of the present discussion is purely on how the relationship varies based on who resides with children 6-15. The basic finding is that household composition attributes that cause children to work more given rice prices are associated with larger declines in child labor. Two interesting exceptions to this general finding are in the data. First, the presence of younger children (0-5) and younger siblings are associated 
with higher levels of own-farm work and smaller declines in own-farm work with rice price increases. Second, the addition of young adults (16-24) lowers the amount of work performed by children 6-15 given rice prices and increases the decline in work associated with rice price increases. Both of these exceptions to the general finding of a positive correlation between initial levels of work and declines in work are consistent with the view that older siblings play a supportive role for their younger siblings.

\subsection{Household Composition}

The framework of section 2 gives two reasons for the effect of rice prices on child labor to depend on household composition. First, household members differ in the value of their marginal product. Second, the household may perceive different marginal disutility of work across children. These two factors imply that income and substitution effects of price changes may vary across members, because the relative (shadow) prices of different forms of labor vary within the household. A third reason (not modeled) that the effect of rice prices on child labor supply may depend on household composition is that the household's decision-making process may depend on who is resident in the household (e.g. Foster 1999) especially if household members benefit from rice price increases differently (e.g. Thomas 1994). This section begins the empirical analysis by considering how the response of child labor supply to rice price changes varies with household composition.

Table 4 allows the effect of rice price increases to vary with household size (in column 1) and counts of the number of persons in the household in various age groups (remaining columns). The sample in table 4 and throughout the remainder of this paper is limited to children ages 6-15 in rural households in communes visited in both rounds of the VLSS. ${ }^{2}$ In the first two

\footnotetext{
${ }^{2}$ In addition, table 4 restricts the sample to children in households with between 3 and 15 members. In practice this eliminates 3 households with more than 20 members and households that consist of only a parent and a child.
} 
columns of table 4, the dependent variable is an indicator for whether the child is active (participates in market work or household production for at least 7 hours in the last week). In columns 3-8, the dependent variable is the hours worked per week in market work (4 and 7), household production (5 and 8), and combined (3 and 6). Columns 3-5 are OLS regressions while columns 6-8 contain results from a Tobit specification. Because the Tobit and OLS results are similar, the discussion focuses on the OLS results. Only OLS results are presented in the remainder of the paper.

Interpreting the results for participation in table 4 requires an understanding of how child labor supply varies with household composition in 1993 after controlling for variation in child labor associated with all of the regression controls in table 4. The coefficient on a non-interacted household composition variable is the relationship between the household composition variable and child labor when the log rice price is zero. The average change in child labor associated with the addition of a person in a given age group is computed by adding the regression coefficient in table 4 for that age group to the product of the coefficient on the interaction of that age group total with the mean log of rice prices (1.05 is the mean log rice price in the pooled 1993 and 1998 data). That is, based on column 2, the average change in the probability that a child is active with the addition of a person between the ages of 0 and 5 is $0.095-0.48 * 1.05$, or each additional child 0-5 increases the probability that a child 6-15 is active by 4 percentage points. By any of the measures in table 4 (i.e. in each column of table 4), child labor is higher when there are more children 0-5 present and lower when there are more young adults (16-24) or prime age adults (25-64) present. With elders (age 65 plus) and persons in the same age category (6-15), more household members in each group is associated with reduced time in household 
work and a reduced probability that a child 6-15 is active. However, more same-age children and more elders are associated with greater participation in market work.

With this baseline perspective, it is possible to interpret how the relationship between child labor and rice prices varies with household composition. In general, the main finding in table 4 is that household composition attributes that are associated with less child labor lead to smaller changes in child labor with rice price increases and attributes associated with more child labor lead to larger reductions in child labor. For example, each additional prime age adult (2564) diminishes the decline in the probability that a child is active with a rice price increase by 3 percentage points (column 2, this is not statistically different than zero) and mitigates the decline in hours in household work with a rice price increase by 1.7 hours (column 5, this is statistically significant). The results of adding an elder (65 plus) are similar in sign to that of adding a primeage adult although they are larger in magnitude and statistically significant in activity (column 2) and household work (column 5). The attenuating effect of the presence of elders on the association between rice prices and child labor may reflect that elders are able to carry more of the household production burden than prime age adults, because elders have diminished obligations to other types of market work as a result of age.

The change in the relationship between child labor and rice prices associated with adding an additional child 0-5 has the opposite sign of the changes associated with adding a prime age adult or elder. Each additional child 0-5 raises the decline in the probability that a child is active with rice price increases by 5 percentage points (column 1, not statistically significant) and increases the decline in hours in household production by 1.9 hours (column 5, statistically significant). This finding that an increase in children 0-5 accentuates the decline in child labor (in columns 2,3,5,6,and 8) for children 6-15 reflects the fact that the presence of a younger child 
is associated with an increase in the probability that a child 6-15 is active and increases the hours worked in household production. One exception to this finding that the presence of a young child increases the decline in child associated with rice price increases (albeit a statistically insignificant results) is that children 6-15 spend more hours in market work with rice price increases.

The more surprising result in table 4 is for the number of persons ages 16 to 24 . Each person age 16 to 24 in the household increases the decline in activity with rice price increases by 5 percentage points (column 2, statistically significant) and the decline in total hours worked by 1.6 hours (column 3, statistically significant). That is, consider the thought experiment of switching a household member from age 6 to 15 to age 16 to 24 . This increases the effect of rice prices on the probability that a child is active by 8 percentage points or approximately 30 percent (evaluated at the 1998 mean of all household composition variables - table 1, column 7). ${ }^{3}$ This though experiment also is associated an additional decline in total hours worked in the last week with rice price increases that is almost 2 hours per week larger. This also corresponds to a 30 percent increase in the magnitude of the effect of rice price increases. This result is surprising, because the presence of a young adult in the household is associated with lower participation rates for children 6 to 15 . That is, the addition of a young adult to the household lowers the incidence of most types of child labor and increases the decline in most types of child labor associated with rice price increases. For this to occur within the model of section 2, the disutility

\footnotetext{
${ }^{3}$ To estimate the thought experiment of keeping household size fixed but moving one household member from one demographic group to another, the marginal effect of a change in rice prices needs to computed for a baseline group. In the present case, the baseline group is given by the study sample means in 1998. To compute the marginal effect of a change in rice prices at the 1998 study sample means on the probability that a child is active, multiply the coefficients on the interaction terms in column 2 of table 4 by their respective means from column 7 of table 1 . Sum these interactions together, adding the regression coefficient on rice prices in the first row that is not interacted with any demographic group. This gives a marginal effect of a change in log rice prices of -0.26 (a 30 percent increase in rice prices is associated with an 8 percentage point decline in the probability that a child 6-15 is active). The thought experiment then subtracts one child 6-15 (-.031) and adds one young adult 16-24 (-.05). The new marginal effect of a change in log rice prices is -0.34 , or 30 percent of the baseline marginal effect.
} 
associated with having a child work needs to be steeper in the relevant ranges than the disutility associated with having the young adult work. This would enable the young adult's child labor to decline with an increase in rice prices but for the child's labor to have to decline proportionally more to maintain equilibrium.

Table 5 looks into what types of activities are changing in greater depth. Columns 1-5 consider participation in wage work, within household work, own-farm work, home enterprises, and household production respectively. Columns 6-9 consider total hours worked in wage work, within household work, within household agriculture, and within household home enterprises. The results for total hours, market work hours, and household production hours are in table 4 and have already been discussed. Table 5 is useful to identify what types of changes in work are behind the patterns observed in table 4 .

The finding that increases in young children (0-5) are associated with smaller declines in hours worked in market work when rice price increases seems to be driven by increased participation in own farm work (column 3 of table 5). Evaluated at the 1998 means (see footnote 3), the marginal effect of a change in rice prices on the probability that a child participates in own farm agriculture is 0.004 . However, if the thought experiment is performed of moving one resident from age group 6-15 to age group 0-5, then the marginal effect of an increase in rice prices on the probability that a child 6-15 participates in own farm agriculture is 0.024 . That is a 530 percent increase in the marginal effect of a change in rice prices based on changing a child's age from the 6-15 range to the 0-5 range. Overall, though, increases in the number of children 05 increase the magnitude of the decline in the probability that a child 6-15 is active (column 2 of table 4) when rice prices increases and lowers the total hours worked by a child (column 3 of table 4) by more when rice prices increase although neither of these findings is statistically 
significant. The larger decline in hours in household production with the addition of a child 0-5 is statistically significant in table 4 (column 5 of table 4), and table 5 illustrates that this decline in household production shows up as a decline in total hours worked within the household (column 7) and in part reflects declines in participation in home production (column 5).

The finding that increases in the number of young adults (16-24) are associated with larger declines in child labor for children 6-15 with rice price increases appears to be driven largely changes in participation in within household work and declines in hours worked in wage work, home enterprise work, and home production. In column 2 of table 5, the addition of a person 16-24 increases the decline in within household work that accompanies increased rice prices by 5 percentage points. This decline in participation in within household work appears to largely be in household production (column 5) even thought the household production coefficient is not statistically significant. The additional decline in hours worked (table 4, column 3 ) seems surprisingly evenly distributed across wage work (table 5 - column 6), work in a home enterprise (table 5 - column 9), and home production (table 4-column 5). There is also an extra decline with an additional person 16-24 in hours in own farm agriculture although it is smaller in magnitude than in the other types of work. Table 5 does not appear to be particularly informative in the types of activities through which additional prime age adults or elders affect smaller declines in most categories in child labor other than the fact that both groups are associated with lower overall participation rates and hours.

Table 6 considers whether there are gender differences in the basic findings of how the relationship between rice prices and child labor varies with household composition. The first 4 columns in table 6 contain the results of restricting the sample to only girls and the last 4 columns restrict the sample to only boys. The dependent variables (columns) are identical to 
columns 2-5 in table 4 . The observation that additional prime age adults and elders are associated with small changes with rice price increases seems to be roughly true in both boys and girls. However, the finding that the addition of young adults leads to larger declines in child labor with rice price increases appears to be entirely a girl phenomena. The patterns observed in boys are similar to that observed in girls, but the magnitudes of the coefficients for boys are substantially smaller. The patterns observed in the changes in the response of child activities to rice price increases with additional young children appears for both boys and girls although they are all statistically insignificant when the data are bifurcated as in table 6. Interestingly, the observation that increased young children 0-5 leads to smaller declines in hours in market work with rice price increases seems to be primarily concentrated in girls although the data do not reject the hypothesis that the gender differences in the coefficients on young children 0-5 and rice prices are in fact zero.

In summary, the data suggest that household composition measures that are associated with less child labor are generally associated with smaller declines in child labor as markets integrate. Equivalently, the largest declines in child labor with market integration are in children who work the most. There are two interesting exceptions to this finding. First, children 6-15 work less in the presence of young adults 16-24, but they also experience larger declines in child labor when rice prices increase. Second, children 6-15 work more in the presence of young children 0-5, and as is typical, children 6-15 experience larger declines in most types of work with rice price increases if there are more children 0-5 in the household. However, the interesting anomaly is that the presence of additional children 0-5 is associated with increases in own farm work with rice price increases for children 6-15. These two anomalies appear to be most important in the labor supply of girls 6-15 rather than boys. They highlight the supportive 
role older children, especially older girls, can play in the household. The next section considers sibling interactions explicitly.

\subsection{Sibling Composition}

The model of section 2 is one in which the effects of rice prices vary with the available substitutes for a child's labor in the household, because a child's relative productivity coupled with the household's marginal disutility of work affects how much the child works in the household. This section considers how the effect of rice prices on a child's labor varies with the number sibling in the household and the gender of these children.

There is a large literature that argues that sibling sex composition may influence investments in children, and Edmonds (2002) finds evidence of a link between sibling gender composition and child labor supply in Nepal. Edmonds contends that differences in comparative advantage in child labor between genders can lead to sibling sex composition effects on child labor. Rose (2000) argues that parental preferences for boys in India cause the investment of parental time in a child to depend on sibling sex composition. Garg and Morduch (1998) as well as Morduch (2000) find in Ghana and Tanzania that in the presence of liquidity constraints, investments in children will be lower with more boys in a household, because boys require more financial resources. Butcher and Case (1994) argue that peer effects are responsible for sibling sex composition effects that they find in the U.S. That is, girls with many brothers grow up in a more masculine environment.

A sibling for this paper is defined as s co-resident person of any age who shares at least one parent in common. A great deal of attention in academic research on southeast Asia has been placed on the responsibilities of the oldest child in the household (see Desai 1999 for discussion in the Vietnamese context). Hence, the empirical work begins by considering 
whether the oldest child is affected by rice prices differently than other child, then turn to a more general specification. Necessarily, to consider sibling composition, the dataset is limited to children with siblings.

The regression approach is to amend (6) to allow rice price effects to vary with an indicator for if a child 6-15 is the oldest sibling. Conditional on being the oldest child, the interpretation of the interaction of rice prices with the oldest child indicator is the change in the effect of rice prices on child labor associated that the oldest child experiences. Table 7 mirrors the format of table 6 and considers whether the oldest child responds differently to changes in rice prices.

Oldest children work more than their siblings even after controlling for the fact that they are older. This is true for both boys and girls. However, the data do not reject the hypothesis that the eldest girls' activities change in the same manner as do her siblings when rice prices change. For boys, the story is different. Being an eldest boy nearly doubles the decline in the probability that a child is active when rice prices increase. The decline in total hours worked is similarly large and occurs in both market and household work although the estimated coefficient for market work is slightly larger (market work and household work hours are individually statistically insignificant). There is no obvious explanation in the theory of section 2 why eldest boys should respond to rice prices so much more than other children in the household. One possibility is that parental preferences to the eldest boy are in someway special so that the disutility from having the eldest boy work is very high. Thus, households are quick to translate additional income from rice price increases into declines in the economic activities of the eldest boy, more so than elder girls for whom work may be more acceptable. 
It seems likely that the consequence of being an older child depends in part on the composition of your sibling cohort. Thus, table 8 considers how the relationship between rice prices and child labor varies with sibling composition. There are 2 panels in table 8 that indicate an entirely distinct set of regressions. In the top panel, the effect of rice prices on child labor is allowed to vary with the number of siblings. In the bottom panel, the effect of rice prices is allowed to vary with the number of siblings, the number of younger siblings, and the number of younger siblings that are male. Each column in table 8 contains the same dependent variable, indicated at the top of the column and defined in the discussion of table 2. Columns 1-4 of table 8 contain results for girls and columns 5-8 refer to boys. Columns 1 and 5 consider changes in whether a child is defined as active. Columns 2-4 (and similarly 5-8) contain hours worked in total, market, and household work respectively. As with each panel, each column is from a distinct regression. Thus, there are sixteen distinct regressions reported in table 8.

For both boys and girls, the data never reject the hypothesis that the effect of rice prices on child labor does not vary with the number of siblings. This mirrors the finding for household size in table 4 and may stem from any number of reasons. For example, older siblings may reduce a child's need to work while younger siblings may increase a child's need to work. On average, these two effects offset so that there does not appear to be an impact of the number of siblings on whether the child is active or how many hours the child works. This example suggests looking at the composition of siblings rather than just their number. Hence, the remainder of this section focuses on the approach in the bottom panel of table 8 that allows effect of rice prices to vary with the number of siblings, the number of younger siblings, and the number of younger male siblings. 
Interpreting the regression coefficients on each of these sibling variables is somewhat tricky, because adding a younger male siblings also adds a younger sibling which also adds a sibling. That is, the change in the effect of rice prices on child labor of adding a younger male sibling is the sum of the coefficient on the younger male sibling interaction term, the younger sibling interaction term, and the sibling interaction term. The change in the effect of rice prices on child labor of adding a younger female sibling is the sum of the coefficients on the younger sibling interaction term and the sibling interaction term. This highlights the main advantage of this specification: the resulting interpretation of each regression coefficient. The interpretation of the interaction with number of younger siblings is given the number of siblings, if a sibling is switched from older to younger than the reference child, how does the response of the child's labor supply to rice prices change. Similarly, the interpretation of the number of younger brothers interaction is the thought experiment of changing a younger sibling from a sister to a brother. The interpretation of the coefficient on the sibling variable is the change in the marginal effect of rice price increases on child labor of adding a sibling who is older.

As with household composition, it is first necessary to understand the link between child labor and sibling composition given rice prices. These statistics are computed at the mean of the log rice price (1.05). For both boys and girls, adding an older sibling decreases the probability that a child is active and the number of hours worked in household production and market work decline. At the mean of log rice prices (1.05), adding an older sibling decreases the probability that a child reports being active by 3 percentage points for both boys and girls and decreases total hours work by 1 hour per week for girls and $1 / 2$ an hour per week for boys. In the thought experiment of converting a sibling from older to younger than the reference child, the amount of work performed by both boys and girls increases. Increases are slightly larger for girls than for 
boys. For both boys and girls, most of the increase in hours worked is in household production. In the thought experiment of converting the younger child from a girl to a boy, both boys and girls increase their work even more. The largest changes are in market work for boys and household production for girls.

Columns 1 and 3 of Table 8 mimic the table 6 regressions but interacting rice prices with the number of siblings rather than children. Sibling results appear similar to the results for children.

An obvious question in the eldest child results is whether the difference experienced by the eldest child is mirrored throughout the sibling order. This is examined in table 8 by interacting rice prices with the number of siblings, the number of younger siblings, and the number of younger brothers. Thus,Column 2 looks at participation in child labor. Column 4 looks at participation without any schooling, and columns 5-7 look at hours worked in total, market, and household work in the last 7 days.

For both boys and girls, an increase in the number of siblings has little effect on how the probability that a child works declines with rice price increases. However, adding a sibling attenuates the increase in girls that only work associated with rice price increases. For both boys and girls, switching a sibling from an older sibling to a younger sibling, increases the effects of rice prices. This appears to be because child labor is higher when there are more younger siblings. Thus, there are greater reductions that can be affected by rice price increases. In general the increasing effects of rice prices with relatively younger siblings are only statistically significant for girls, but the estimates of the magnitude of the change in rice price effects with adding younger siblings appears similar for both boys and girls. 
While younger siblings increase the decline in participation in child labor associated with rice price increases, a change in the gender mix of those younger siblings towards boys actually mitigates the effects of adding younger siblings for girls. For boys the net effect is still a larger decline in child labor with additional siblings, but younger brothers mitigate the effects of rice prices while younger sisters increase the effects of rice prices. This rather odd result appears to be because the child labor participation of girls is lower in the presence of younger brothers than it is in the presence of younger sisters. In examining hours worked, it appears that this lower participation rate of girls is because adding younger brothers lowers the time that girls (and boys) spend in market work. One possible explanation for this is that perhaps younger brothers are better own-farm workers than are girls. Thus, the presence of younger brothers lowers the household's labor demand for girls in market work.

\section{Conclusion}

This study has considered how the response of child labor supply to product market integration varies with the child's household and sibling composition. A simple theoretical model illustrates that the response of child labor supply to product market integration should depend on household and sibling composition. In general, the household allocates child labor so that the relatively more productive children work more. More productive children experience larger swings in child labor supply with relative price increases. If child labor declines with price increases, then more productive children experience large declines. If child labor increases with price increases, then more productive children experience larger increases.

The empirical findings are broadly consistent with this theoretical result. In general, rice price increases are associated with declines in child labor in Vietnam. Theoretically, this 
suggests a positive income effect to rice producing households, a substitution effect away from rice toward child leisure, and a substitution effect away from children in the production of rice. Older children are relatively more productive within the household, and older children work more in the absence of price increases. In most cases, these older children experience larger declines in child labor than their younger siblings with increases in rice prices, even after controlling for differences in child labor associated with age.

This study finds that adding a child or a sibling to a household does not have a clear effect on how a given child's labor supply responds to rice price increases. This appears to be because a child's response to the addition of a co-resident child or sibling depends on that child's relative productivity. If the additional child is older than the reference child, then the reference child's labor is lower as a result of the presence of the older, more productive child. Because the reference child's initial labor supply is lower, rice price increases lead to a smaller decline in child labor. The converse appears to be true for the addition of a younger child. That is, when the reference child is older, the addition of a younger sibling increases the reference child's initial labor supply and thereby the reference child experiences a larger decline in child labor with rice price increases. These two responses to the addition of a child or sibling offset each other so that the net effect of adding a co-resident child or sibling is zero on average.

This reason for no effect on child labor participation of adding a sibling highlights a main finding of this paper: there are large differences in how child labor responds to rice prices associated with whether the reference child's cohort of siblings is relatively younger or older. The greater the fraction of siblings that are younger, the more the reference child works and therefore the larger the reduction in child labor with rice price increases for the reference child. These results are particularly large for the eldest child. Eldest siblings work substantially more 
than younger siblings and experience much larger declines in child labor with rice price increases. The effects of rice prices on the eldest child are particularly dramatic for the eldest boy. Girls generally work more than boys and generally experience larger declines in child labor with rice price increases. However, if the eldest child is a boy, he appears to bear a greater work burden than the standard boy. Thus, with an increase in rice prices, he experiences the largest declines in child labor supply.

The results for child labor overall differ slightly from those for working and not attending school (child labor only). Vietnam has among the shortest school days in the developing world, so school and work are often compatible. There is some concern, however, that children that work and do not attend school are somehow bearing a greater cost than children that work and attend school. Girls are more likely to work and not attend school, and their propensity to do this appears to depend on the number of siblings. In considering hours worked, it looks like girls spend more time in household production when there are more children in the household (even if the children are older or younger). This, then, leads to a lower probability of participating in schooling while working. However, with rice price increases, these girls experience larger declines in child labor supply with the number of siblings in the household. The effect of rice price increases is further magnified if these siblings are younger siblings. Hence, for girls, both sibling age composition and sibling cohort size appear to be important in how the probability a child works without attending school responds to rice price increases.

Overall, then, this study has found that children who work more experience larger declines in child labor. Household and sibling composition variables associated with differences in child labor are then associated with differences in declines in child labor. Thus, differences between siblings in child labor are elastic with respect to the household's environment. Customs 
and social norms may produce the observed differences between siblings in productivity or the household's willingness to let a child work. However, the results of this study suggest that economic factors such as the relative price changes studied here can work to mitigate sibling differences. This may have implications for the long-term persistence of sibling differences in the development process.

There is one interesting result where children that work more are not the ones experiencing the largest declines in child labor. Namely, children work less in the presence of young adults ages 16 to 24 . Yet, children 6 to 15 experience larger reductions in child labor supply with increases in rice prices if there are more young adults 16 to 24 present. Edmonds and Pavcnik (2003b) find net declines in the labor supply of young adults with rice price increases, but the results in the present paper suggest that part of what must be occurring is that the households are also substituting some additional work of persons 16 to 24 for child labor. This might occur within the framework of section 2 if the household perceives a different disutility of work for children than it does for young adults.

Overall, then the results of this study are consistent with a general convergence of labor supply between children with product market integration. In fact, the broader data suggest child labor supply is converging within the household in Vietnam. 49 percent of the variation in child labor is within household in 1993 while only 38 percent is within household in 1998. Thus, variation in child labor between co-resident children declines by 22 percent. The convergence in co-resident variation in child labor that is attributable to rice prices occurs, because the net effect of all of the substitution and income effects associated with market integration in this context are toward a decline in child labor. An obvious question arises about how these results generalize. First, for reasons discussed in Edmonds and Pavcnik (2002c), the sign of the effect of market 
integration on child labor may be unique to the present case where most households are wellpositioned to benefit from an increase in the relative price of rice. Second, it could be the case that ethnic traditions and social norms are weaker in Vietnam than in other countries where they are believed to be important. Thus, economic factors have a greater ability to influence sibling differences in child labor in Vietnam than elsewhere.

\section{References}

Basu, K. (1999): "Child Labor: Cause, Consequence, and Cure, with Remarks on International Labor Standards,” Journal of Economic Literature, 37, 1083-1119.

Basu, K. and Z. Tzannatos (2003). "The Global Child Labor Problem: What do we know and what can we do?” World Bank Economic Review, forthcoming.

Basu, K. and P. H. Van (1998). “The Economics of Child Labor,” American Economic Review, 88, 412-427.

Behrman, J, Taubman, P. (1986): “Birth Order, Schooling, and Earnings,” Journal of Labor Economics, 4(3), S121-S150.

Benjamin, D., Brandt, L. (2004): "Agriculture and Income Distribution in Rural Vietnam under Economic Reforms: A Tale of Two Regions," ." in P. Glewwe, N. Agrawal and D. Dollar (eds), Economic Growth, Poverty and Household Welfare: Policy Lessons from Vietnam. Washington DC: World Bank.

Birdsall, N. (1991): "Birth Order Effects and Time Allocation," Research in Population Economics, T. P. Shultz, ed., Volume 7, 191-213.

Butcher, K. and A. Case (1994): “The Effect of Sibling Sex Composition on Women's Education and Earnings," Quarterly Journal of Economics, 109(3), 531-563.

Collier, P. and Dollar, D (2002): Globalization, Growth, and Poverty, Washington DC: World Bank and Oxford University Press.

Ejrnæs, M. and C. Chr. Pörtner (2000): "Birth Order and the Intrahousehold Allocation of Time and Education," Institute of Economics, University of Copenhagen Manuscript.

Edmonds, E. (2002): “Understanding Sibling Differences in Child Labor.” Dartmouth College Manuscript.

Edmonds, E, K. Mammen, and D. L. Miller (2002): "Rearranging the Family? Household Composition Responses to Large Pension Receipts.” Dartmouth College Manuscript.

Edmonds, E., Pavcnik, N. (2003a): "The Effect of Trade Liberalization on Child Labor." Dartmouth College Manuscript. 
Edmonds, E., Pavcnik, N. (2003b): "International Product Market Integration and Household Labor Supply in a Poor Economy: Evidence from Vietnam.” Dartmouth College Manuscript.

Edmonds, E., Pavcnik, N. (2003c): "The Relationship between Product Market Integration and Child Labor Supply: Evidence from Vietnam," Dartmouth College Manuscript and formerly "Does Globalization Increase Child Labor? Evidence from Vietnam.” NBER Working Paper \#8760.

Edmonds, E., Turk, C. (2004): "Child Labor in Transition." in P. Glewwe, N. Agrawal and D. Dollar (eds), Economic Growth, Poverty and Household Welfare: Policy Lessons from Vietnam. Washington DC: World Bank.

Emerson and Portela, A. (2002): 'Birth Order, Child Labor and School Attendance in Brazil', manuscript: University of Colorado, Denver.

Foster, A. (1999): “Altruism, Household Coresidence and Women’s Health Investment in Bangladesh," Brown University Manuscript.

Garg, A. and J. Morduch (1998): "Sibling Rivalry and the Gender Gap: Evidence from Child Health Outcomes in Ghana," Journal of Population Economics, 11, 471-493.

Glewwe, P. and P. Nguyen (2004): "Economic Mobility in Vietnam in the 1990s." ." in P. Glewwe, N. Agrawal and D. Dollar (eds), Economic Growth, Poverty and Household Welfare: Policy Lessons from Vietnam. Washington DC: World Bank..

Grootaert, K. and H. Patrinos (1999): The Policy Analysis of Child Labor: A Comparative Study. St. Martin's Press: New York.

Krugman, P (1991): Geography and Trade, Cambridge: MIT Press.

Leamer, E. and J. Levinsohn (1995): International Trade Theory: The Evidence in Grossman G. and K. Rogoff (eds.) Handbook of International Economics: Elsevier

Levison, D., R. Anker, S. Ashraf, and S. Barge (1998). "Is Child Labor Really Necessary in India’s Carpet Industry,” in R. Anker, S. Barge, S. Rajagopal, and M.P. Joseph (eds.). Economics of Child Labor in Hazardous Industries in India. New Delhi: Hindustan Publishers.

Morduch, Jonathan (2000): "Sibling Rivalry in Africa," American Economic Association Papers and Proceedings, May 2000.

Parish, W. and R. Willis (1993): "Daughters, Education, and Family Budgets: Taiwan Experiences" Journal of Human Resources, 28(4), 862-898.

Poverty and Human Resources Division of the World Bank (2000): "Vietnam Living Standards Survey, 1997-98: Basic Information." Manuscript.

Thomas, D. (1994): "Like Father, Like Son; Like Mother, Like Daughter: Parental Resources and Child Height," Journal of Human Resources, 29(4), 950-988. 
Table 1: Household Structures in Vietnam

\begin{tabular}{|c|c|c|c|c|c|c|c|c|}
\hline & \multicolumn{4}{|c|}{ " Nationally Representative Sample } & \multicolumn{4}{|c|}{ "Study Sample } \\
\hline & 1993 & & 1998 & & 1993 & & 1998 & \\
\hline & -1 & -2 & -3 & -4 & -5 & -6 & -7 & -8 \\
\hline & mean & s.e. & mean & s.e. & mean & s.e. & mean & s.e. \\
\hline \multicolumn{9}{|l|}{ HH variables } \\
\hline \# Sample Households & 4799 & & 5999 & & 2255 & & 2375 & \\
\hline \# Communes (PSU) & 150 & & 194 & & 115 & & 115 & \\
\hline Household Size & 5.91 & 0.09 & 5.48 & 0.06 & 6.55 & 0.11 & 5.95 & 0.08 \\
\hline \# Persons 0-5 & 0.87 & 0.03 & 0.57 & 0.02 & 0.88 & 0.04 & 0.56 & 0.03 \\
\hline \# Persons 6-15 & 1.61 & 0.04 & 1.46 & 0.04 & 2.34 & 0.03 & 2.14 & 0.04 \\
\hline \# Persons 16-24 & 1.05 & 0.03 & 1.00 & 0.03 & 1.00 & 0.04 & 0.93 & 0.04 \\
\hline \# Persons 25-64 & 2.11 & 0.04 & 2.12 & 0.02 & 2.09 & 0.03 & 2.09 & 0.02 \\
\hline \# Persons 65+ & 0.28 & 0.01 & 0.33 & 0.01 & 0.23 & 0.01 & 0.24 & 0.01 \\
\hline \multicolumn{9}{|c|}{ Variables for Children 6-15 } \\
\hline Mother Present & 0.96 & 0.00 & 0.96 & 0.00 & 0.96 & 0.00 & 0.97 & 0.00 \\
\hline Father Present & 0.88 & 0.01 & 0.91 & 0.01 & 0.89 & 0.01 & 0.92 & 0.01 \\
\hline Both Parents Present & 0.87 & 0.01 & 0.89 & 0.01 & 0.88 & 0.01 & 0.90 & 0.01 \\
\hline \# Co-Resident Siblings & 3.17 & 0.07 & 2.63 & 0.07 & 3.30 & 0.07 & 2.71 & 0.08 \\
\hline Fraction Brothers & 0.50 & 0.01 & 0.51 & 0.01 & 0.50 & 0.01 & 0.51 & 0.01 \\
\hline Fraction Younger & 0.48 & 0.01 & 0.45 & 0.01 & 0.49 & 0.01 & 0.45 & 0.01 \\
\hline
\end{tabular}

All means are weighted to reflect sample design. All standard errors are corrected for primary sampling unit (psu) clustering.

The study sample is restricted to rural households with children 6-15 in communes that are visited in both rounds of the VLSS. 
Table 2: Activities of Children Aged 6-15

limited to children in rural households in panel communities

\begin{tabular}{|c|c|c|c|c|c|c|c|c|}
\hline & \multirow{4}{*}{$\begin{array}{c}\text { Female } \\
1993 \\
-1 \\
\text { mean }\end{array}$} & \multicolumn{7}{|c|}{ Male } \\
\hline & & \multicolumn{3}{|c|}{1998} & 1993 & \multicolumn{3}{|c|}{1998} \\
\hline & & -2 & -3 & -4 & -5 & -6 & -7 & -8 \\
\hline & & s.e. & mean & s.e. & mean & s.e. & mean & s.e. \\
\hline \multicolumn{9}{|l|}{ 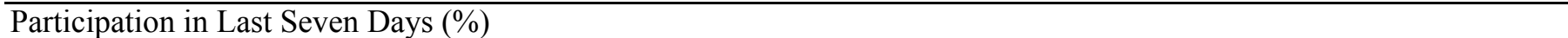 } \\
\hline Wage Work & 2.2 & 0.5 & 1.4 & 0.3 & 1.9 & 0.4 & 1.1 & 0.3 \\
\hline Agriculture & 1.5 & 0.4 & 0.9 & 0.3 & 1.4 & 0.3 & 0.7 & 0.2 \\
\hline Non-Agricultural activities & 0.7 & 0.2 & 0.5 & 0.2 & 0.6 & 0.2 & 0.5 & 0.2 \\
\hline$\underline{\text { Within Household Work }}$ & 69.0 & 1.4 & 64.3 & 1.9 & 60.8 & 1.7 & 56.6 & 2.2 \\
\hline Agriculture & 30.8 & 2.0 & 24.1 & 2.1 & 29.3 & 2.0 & 23.6 & 2.4 \\
\hline Household Enterprise & 4.9 & 0.9 & 2.8 & 0.7 & 3.5 & 0.6 & 2.8 & 0.6 \\
\hline Household Production & 62.6 & 1.4 & 62.7 & 1.9 & 47.7 & 1.7 & 50.6 & 2.3 \\
\hline Market Work & 35.8 & 1.8 & 27.0 & 2.0 & 33.4 & 1.9 & 26.1 & 2.4 \\
\hline$\underline{\text { Any Work }}$ & 69.4 & 1.4 & 64.6 & 1.9 & 61.9 & 1.7 & 57.2 & 2.2 \\
\hline$\underline{\text { Active }}$ & 63.7 & 1.5 & 52.0 & 2.3 & 56.3 & 1.7 & 45.0 & 2.5 \\
\hline \multicolumn{9}{|l|}{ Hours Worked per Week } \\
\hline Wage Work & 0.46 & 0.10 & 0.34 & 0.08 & 0.44 & 0.11 & 0.28 & 0.06 \\
\hline Agriculture & 0.33 & 0.09 & 0.22 & 0.07 & 0.34 & 0.09 & 0.20 & 0.05 \\
\hline Nonagricultural activities & 0.14 & 0.05 & 0.11 & 0.04 & 0.09 & 0.06 & 0.09 & 0.03 \\
\hline$\underline{\text { Within Household Work }}$ & 14.58 & 0.59 & 10.63 & 0.59 & 11.22 & 0.56 & 8.47 & 0.55 \\
\hline Agriculture & 6.17 & 0.50 & 4.51 & 0.47 & 6.08 & 0.49 & 4.35 & 0.42 \\
\hline Household Enterprise & 0.85 & 0.23 & 0.46 & 0.12 & 0.41 & 0.09 & 0.23 & 0.05 \\
\hline Household Production & 7.59 & 0.25 & 5.65 & 0.26 & 4.73 & 0.26 & 3.88 & 0.27 \\
\hline Market Work & 7.48 & 0.50 & 5.31 & 0.45 & 6.94 & 0.47 & 4.86 & 0.41 \\
\hline Total Hours & 15.05 & 0.60 & 10.98 & 0.58 & 11.67 & 0.55 & 8.75 & 0.53 \\
\hline Sample Size & 2370 & & 2287 & & 2481 & & 2456 & \\
\hline
\end{tabular}

All means are weighted to reflect sample design and standard errors are corrected for PSU clustering. Market work includes work for wages, work in agriculture within the household, and work in household enterprise. Because people can paricipate in more than one activity the subcotegories of various participation variables do not necessarily add up to participation in wage work, within household work, and overall(any) work. Active is defined as participating in market work or participating in household production for at least 7 hours in the last week. 
Table 3: Household Composition and Child Labor

limited to children 6-15 in rural households in panel communities 1993 and 1998 data are combined for this table

\begin{tabular}{|c|c|c|c|c|}
\hline & Active $=1$ & & Active $=0$ & \\
\hline & -1 & -2 & -3 & -4 \\
\hline \multirow[t]{2}{*}{ Sample Size } & 5062 & & 4491 & \\
\hline & mean & s.e. & mean & s.e. \\
\hline Household Size & 6.103 & 0.080 & 6.187 & 0.101 \\
\hline \# Persons 0-5 & 0.605 & 0.035 & 0.614 & 0.033 \\
\hline \# Persons 6-15 & 2.570 & 0.035 & 2.545 & 0.040 \\
\hline \# Persons 16-24 & 0.750 & 0.029 & 0.762 & 0.040 \\
\hline \# Persons 25-64 & 1.993 & 0.011 & 2.066 & 0.019 \\
\hline \# Persons 65+ & 0.187 & 0.012 & 0.204 & 0.013 \\
\hline \# Siblings & 3.018 & 0.073 & 2.968 & 0.081 \\
\hline \# Younger Sibs & 1.632 & 0.053 & 1.017 & 0.037 \\
\hline \# Younger Brothers & 0.840 & 0.033 & 0.521 & 0.023 \\
\hline
\end{tabular}


Table 4: Household Composition, Rice Prices, and Child Labor

limited to children 6-15 in households with 3-15 members

\begin{tabular}{|c|c|c|c|c|c|c|c|c|}
\hline \multirow[b]{3}{*}{ Dependent Variable: } & \multicolumn{2}{|c|}{ Participation } & \multicolumn{3}{|c|}{ Hours Worked - OLS } & \multicolumn{3}{|c|}{ Hours Worked - Tobit } \\
\hline & -1 & -2 & -3 & -4 & -5 & -6 & -7 & -8 \\
\hline & \multicolumn{2}{|c|}{ Active } & Total & Market & Household & Total & Market & Household \\
\hline \multirow[t]{2}{*}{ Rice Price } & -0.231 & -0.345 & -9.528 & -3.508 & -6.013 & -7.88 & -3.492 & -6.326 \\
\hline & {$[0.110]^{* *}$} & {$[0.127]^{* *}$} & {$[3.742]^{* *}$} & [3.140] & {$[2.183]^{* *}$} & {$[4.586]^{*}$} & [7.184] & {$[3.107]^{* *}$} \\
\hline \multirow[t]{2}{*}{ Rice Price * Household Size } & -0.003 & & & & & & & \\
\hline & [0.015] & & & & & & & \\
\hline \multirow[t]{2}{*}{ Rice Price * \# People 0-5 } & & -0.048 & -1.329 & 0.571 & -1.845 & -2.682 & 0.575 & -2.958 \\
\hline & & [0.032] & [0.882] & [0.633] & {$[0.630]^{* *}$} & {$[1.201]^{* *}$} & [1.934] & {$[0.808]^{* *}$} \\
\hline \multirow[t]{2}{*}{ Rice Price * \# People 6-15 } & & 0.031 & 0.245 & -0.194 & 0.383 & 0.487 & 0.846 & 0.504 \\
\hline & & [0.025] & [0.655] & [0.524] & [0.378] & {$[0.866]$} & [1.375] & [0.583] \\
\hline \multirow[t]{2}{*}{ Rice Price * \# People 16-24 } & & -0.05 & -1.614 & -1.006 & -0.597 & -2.281 & 0.274 & -1.168 \\
\hline & & {$[0.025]^{* *}$} & {$[0.691]^{* *}$} & {$[0.597]^{*}$} & [0.411] & {$[0.893]^{* *}$} & [1.394] & {$[0.610]^{*}$} \\
\hline \multirow[t]{2}{*}{ Rice Price * \# People 25-64 } & & 0.03 & 2.01 & 0.264 & 1.744 & 1.694 & -1.567 & 2.475 \\
\hline & & [0.047] & [1.397] & [1.226] & {$[0.834]^{* *}$} & [1.770] & {$[2.771]$} & {$[1.204]^{* *}$} \\
\hline \multirow[t]{2}{*}{ Rice Price * \# People 65+ } & & 0.12 & 2.031 & -0.078 & 2.104 & 3.011 & -1.796 & 3.007 \\
\hline & & {$[0.046]^{* *}$} & [1.386] & [1.218] & {$[0.748]^{* *}$} & [1.912] & [2.971] & {$[1.302]^{* *}$} \\
\hline \multirow[t]{2}{*}{ Household size } & -0.007 & & & & & & & \\
\hline & [0.016] & & & & & & & \\
\hline \multirow[t]{2}{*}{ \# People 0-5 } & & 0.095 & 2.388 & -0.331 & 2.673 & 4.718 & 0.548 & 4.458 \\
\hline & & {$[0.035]^{* *}$} & {$[0.970]^{* *}$} & [0.679] & {$[0.713]^{* *}$} & {$[1.264]^{* *}$} & [2.017] & {$[0.852]^{* *}$} \\
\hline \multirow[t]{2}{*}{ \# People 6-15 } & & -0.038 & -0.347 & 0.377 & -0.668 & -1.094 & -0.461 & -1.183 \\
\hline & & [0.027] & [0.743] & [0.572] & [0.432] & [0.926] & [1.461] & {$[0.624]^{*}$} \\
\hline \multirow[t]{2}{*}{ \# People 16-24 } & & 0.022 & 0.891 & 0.918 & -0.053 & 0.852 & -0.783 & -0.252 \\
\hline & & [0.028] & [0.792] & [0.663] & [0.462] & [0.954] & [1.478] & [0.651] \\
\hline \multirow[t]{2}{*}{ \# People 25-64 } & & -0.07 & -3.15 & -0.619 & -2.525 & -3.457 & 0.452 & -3.761 \\
\hline & & [0.052] & {$[1.455]^{* *}$} & [1.287] & {$[0.943]^{* *}$} & {$[1.868]^{*}$} & [2.900] & {$[1.275]^{* *}$} \\
\hline \multirow[t]{2}{*}{ \# People 65+ } & & -0.145 & -2.6 & 0.095 & -2.715 & -4.196 & 1.902 & -4.194 \\
\hline & & {$[0.051]^{* *}$} & {$[1.569]^{*}$} & [1.404] & {$[0.825]^{* *}$} & {$[2.054]^{* *}$} & [3.163] & {$[1.400]^{* *}$} \\
\hline Observations & 9470 & 9470 & 9457 & 9503 & 9464 & 9457 & 9503 & 9464 \\
\hline R-squared & 0.38 & 0.39 & 0.44 & 0.36 & 0.25 & & & \\
\hline
\end{tabular}

Notes: Each column is a separate regression. For variable definitions, see text. Robust standard errors in brackets are corrected for psu-time clustering. * significant at $10 \%$; $* *$ significant at $5 \%$. All regressions include commune fixed effects, third order polynomial in age, a gender indicator, interactions of the gender dummy with all of the terms of the age polynomial, a year effect, interaction of the year effect with regions, interaction of commune accessibility with year, controls for the season of interview and whether the interview is at a rice harvest or planting time. The number of observations are smaller in the hours worked columns because of missing data. Some observations with missing hours can be recovered in participation (cols 1-2) when participation in one of the types of work is positive. See table 2 for description of dependent variables. 
Table 5: Household Composition, Rice Prices, and the type of Activity

limited to children 6-15 in households with 3-15 members

\begin{tabular}{|c|c|c|c|c|c|c|c|c|c|}
\hline \multirow[b]{4}{*}{ Dependent Variable: } & \multicolumn{5}{|c|}{ Participation } & \multicolumn{4}{|c|}{ Hours - OLS } \\
\hline & -1 & -2 & -3 & $\begin{array}{l}-4 \\
\text { Within }\end{array}$ & -5 & -6 & -7 & -8 & $\begin{array}{l}-9 \\
\text { Within }\end{array}$ \\
\hline & Wage & Within & Within & Hh Home & Within $\mathrm{Hh}$ & Wage & Within & Within & Hh Home \\
\hline & Work & Hh Work & Hh Agr & Ent & Home Prod & Work & Hh Work & Hh Agr & Ent \\
\hline Rice Price & $\begin{array}{l}0 \\
{[0.061]}\end{array}$ & $\begin{array}{l}0.05 \\
{[0.134]}\end{array}$ & $\begin{array}{l}0.053 \\
{[0.129]}\end{array}$ & $\begin{array}{l}-0.015 \\
{[0.053]}\end{array}$ & $\begin{array}{l}-0.05 \\
{[0.158]}\end{array}$ & $\begin{array}{l}-1.639 \\
{[1.748]}\end{array}$ & $\begin{array}{l}-7.894 \\
{[3.475]^{* *}}\end{array}$ & $\begin{array}{l}-0.168 \\
{[2.493]}\end{array}$ & $\begin{array}{l}-1.704 \\
{[1.163]}\end{array}$ \\
\hline Rice Price * \# People 0-5 & $\begin{array}{l}0.004 \\
{[0.009]}\end{array}$ & $\begin{array}{l}-0.06 \\
{[0.034]^{*}}\end{array}$ & $\begin{array}{l}0.058 \\
{[0.029]^{* *}}\end{array}$ & $\begin{array}{l}0.014 \\
{[0.016]}\end{array}$ & $\begin{array}{l}-0.076 \\
{[0.037]^{* *}}\end{array}$ & $\begin{array}{l}0.119 \\
{[0.229]}\end{array}$ & $\begin{array}{l}-1.463 \\
{[0.851]^{*}}\end{array}$ & $\begin{array}{l}0.612 \\
{[0.647]}\end{array}$ & $\begin{array}{l}-0.177 \\
{[0.335]}\end{array}$ \\
\hline Rice Price * \# People 6-15 & $\begin{array}{l}0 \\
{[0.008]}\end{array}$ & $\begin{array}{l}0.036 \\
{[0.024]}\end{array}$ & $\begin{array}{l}0.005 \\
{[0.021]}\end{array}$ & $\begin{array}{l}0.005 \\
{[0.011]}\end{array}$ & $\begin{array}{l}0.007 \\
{[0.028]}\end{array}$ & $\begin{array}{l}0.087 \\
{[0.207]}\end{array}$ & $\begin{array}{l}0.138 \\
{[0.647]}\end{array}$ & $\begin{array}{l}-0.345 \\
{[0.463]}\end{array}$ & $\begin{array}{l}0.044 \\
{[0.189]}\end{array}$ \\
\hline Rice Price * \# People 16-24 & $\begin{array}{l}-0.006 \\
{[0.009]}\end{array}$ & $\begin{array}{l}-0.048 \\
{[0.026]^{*}}\end{array}$ & $\begin{array}{l}0.021 \\
{[0.023]}\end{array}$ & & & $\begin{array}{l}-0.369 \\
{[0.286]}\end{array}$ & $\begin{array}{l}-1.246 \\
{[0.642]^{*}}\end{array}$ & $\begin{array}{l}-0.185 \\
{[0.522]}\end{array}$ & $\begin{array}{l}-0.453 \\
{[0.261]^{*}}\end{array}$ \\
\hline Rice Price * \# People 25-64 & $\begin{array}{l}-0.01 \\
{[0.028]}\end{array}$ & $\begin{array}{l}-0.012 \\
{[0.054]}\end{array}$ & $\begin{array}{l}-0.046 \\
{[0.043]}\end{array}$ & $\begin{array}{l}-0.021 \\
{[0.019]}\end{array}$ & $\begin{array}{l}0.09 \\
{[0.062]}\end{array}$ & $\begin{array}{l}0.77 \\
{[0.721]}\end{array}$ & $\begin{array}{l}1.272 \\
{[1.229]}\end{array}$ & & $\begin{array}{l}0.381 \\
{[0.398]}\end{array}$ \\
\hline Rice Price * \# People 65+ & $\begin{array}{l}0.003 \\
{[0.012]}\end{array}$ & $\begin{array}{l}0.045 \\
{[0.046]}\end{array}$ & $\begin{array}{l}-0.064 \\
{[0.042]}\end{array}$ & $\begin{array}{l}0.041 \\
{[0.025]}\end{array}$ & $\begin{array}{l}0.033 \\
{[0.046]}\end{array}$ & $\begin{array}{l}0.385 \\
{[0.378]}\end{array}$ & $\begin{array}{l}1.609 \\
{[1.424]}\end{array}$ & $\begin{array}{l}-1.579 \\
{[1.198]}\end{array}$ & $\begin{array}{l}1.081 \\
{[0.465]^{* *}}\end{array}$ \\
\hline \# People 0-5 & $\begin{array}{l}-0.001 \\
{[0.011]}\end{array}$ & $\begin{array}{l}0.099 \\
{[0.037]^{* *}}\end{array}$ & $\begin{array}{l}-0.046 \\
{[0.031]}\end{array}$ & $\begin{array}{l}-0.017 \\
{[0.018]}\end{array}$ & $\begin{array}{l}0.116 \\
{[0.040]^{* *}}\end{array}$ & $\begin{array}{l}-0.076 \\
{[0.261]}\end{array}$ & $\begin{array}{l}2.483 \\
{[0.935]^{* *}}\end{array}$ & $\begin{array}{l}-0.36 \\
{[0.704]}\end{array}$ & $\begin{array}{l}0.127 \\
{[0.386]}\end{array}$ \\
\hline \# People 6-15 & $\begin{array}{l}-0.001 \\
{[0.009]}\end{array}$ & $\begin{array}{l}-0.052 \\
{[0.026]^{* *}}\end{array}$ & $\begin{array}{l}0.008 \\
{[0.023]}\end{array}$ & $\begin{array}{l}-0.002 \\
{[0.013]}\end{array}$ & $\begin{array}{l}-0.024 \\
{[0.030]}\end{array}$ & $\begin{array}{l}-0.1 \\
{[0.228]}\end{array}$ & $\begin{array}{l}-0.221 \\
{[0.729]}\end{array}$ & $\begin{array}{l}0.527 \\
{[0.503]}\end{array}$ & $\begin{array}{l}-0.024 \\
{[0.220]}\end{array}$ \\
\hline \# People 16-24 & $\begin{array}{l}0.007 \\
{[0.011]}\end{array}$ & $\begin{array}{l}0.01 \\
{[0.030]}\end{array}$ & $\begin{array}{l}-0.03 \\
{[0.025]}\end{array}$ & $\begin{array}{l}0.002 \\
{[0.016]}\end{array}$ & $\begin{array}{l}-0.018 \\
{[0.033]}\end{array}$ & $\begin{array}{l}0.354 \\
{[0.322]}\end{array}$ & $\begin{array}{l}0.54 \\
{[0.739]}\end{array}$ & $\begin{array}{l}0.123 \\
{[0.573]}\end{array}$ & $\begin{array}{l}0.445 \\
{[0.309]}\end{array}$ \\
\hline \# People 25-64 & $\begin{array}{l}0.004 \\
{[0.032]}\end{array}$ & $\begin{array}{l}-0.011 \\
{[0.060]}\end{array}$ & $\begin{array}{l}0.05 \\
{[0.048]}\end{array}$ & $\begin{array}{l}0.011 \\
{[0.020]}\end{array}$ & $\begin{array}{l}-0.127 \\
{[0.069]^{*}}\end{array}$ & $\begin{array}{l}-1.135 \\
{[0.816]}\end{array}$ & $\begin{array}{l}-2.044 \\
{[1.249]}\end{array}$ & $\begin{array}{l}1.065 \\
{[1.134]}\end{array}$ & $\begin{array}{l}-0.579 \\
{[0.421]}\end{array}$ \\
\hline \# People 65+ & $\begin{array}{l}-0.009 \\
{[0.014]}\end{array}$ & $\begin{array}{l}-0.075 \\
{[0.050]}\end{array}$ & $\begin{array}{l}0.079 \\
{[0.047]^{*}}\end{array}$ & $\begin{array}{l}-0.047 \\
{[0.029]^{*}}\end{array}$ & $\begin{array}{l}-0.068 \\
{[0.052]}\end{array}$ & $\begin{array}{l}-0.582 \\
{[0.433]}\end{array}$ & $\begin{array}{l}-1.981 \\
{[1.604]}\end{array}$ & $\begin{array}{l}1.96 \\
{[1.383]}\end{array}$ & $\begin{array}{l}-1.248 \\
{[0.528]^{* *}}\end{array}$ \\
\hline & 9510 & 9510 & 9510 & 9510 & 9465 & 9503 & 9457 & 9503 & 9503 \\
\hline R-squared & 0.07 & 0.39 & 0.35 & 0.12 & 0.32 & 0.07 & 0.44 & 0.36 & 0.1 \\
\hline
\end{tabular}

See notes to table 4 for other notes about the regressions. See table 2 for description of dependent variables. Robust standard errors in brackets are corrected for psu-time clustering. * significant at $10 \%$. ** Significant at $5 \%$. 
Table 6: Household Composition, Rice Prices, and Child Labor by Gender

limited to children 6-15 in households with 3-15 members

\begin{tabular}{|c|c|c|c|c|c|c|c|c|}
\hline & Girls & & & & Boys & & & \\
\hline & Participati & Houl & Irs Worked & (OLS) & Participati & Hour & rs Workec & (OLS) \\
\hline & -1 & -2 & -3 & -4 & -5 & -6 & -7 & -8 \\
\hline Dependent Variable: & Active & Total & Market & Household & Active & Total & Market & Household \\
\hline Rice Price & -0.281 & -14.144 & -7.045 & -7.294 & -0.399 & -5.222 & -0.121 & -4.909 \\
\hline & {$[0.161]^{*}$} & {$[5.044]^{* *}$} & {$[3.624]^{*}$} & {$[3.203]^{* *}$} & {$[0.167]^{* *}$} & [4.683] & [4.305] & {$[2.568]^{*}$} \\
\hline Rice Price * \# People 0-5 & -0.026 & -0.22 & 1.21 & -1.235 & -0.064 & -1.855 & 0.253 & -2.172 \\
\hline & {$[0.042]$} & [1.307] & [0.919] & [1.009] & {$[0.044]$} & [1.164] & [1.039] & {$[0.657]^{* *}$} \\
\hline Rice Price * \# People 6-15 & 0.014 & 0.793 & -0.036 & 0.753 & 0.05 & 0.007 & -0.239 & 0.182 \\
\hline & {$[0.033]$} & {$[0.915]$} & {$[0.690]$} & [0.604] & {$[0.032]$} & {$[0.775]$} & {$[0.614]$} & {$[0.446]$} \\
\hline Rice Price * \# People 16-24 & -0.078 & -2.139 & -1.345 & -0.779 & -0.017 & -1.017 & -0.739 & -0.281 \\
\hline & {$[0.033]^{* *}$} & {$[0.881]^{* *}$} & {$[0.726]^{*}$} & {$[0.580]$} & {$[0.033]$} & {$[0.943]$} & {$[0.828]$} & {$[0.490]$} \\
\hline Rice Price * \# People 25-64 & 0.009 & 2.696 & 1.103 & 1.616 & 0.037 & 0.875 & -0.643 & 1.521 \\
\hline & {$[0.063]$} & {$[2.063]$} & [1.507] & {$[1.356]$} & {$[0.068]$} & [1.844] & {$[1.753]$} & {$[0.918]^{*}$} \\
\hline Rice Price * \# People 65+ & 0.151 & 2.296 & -0.454 & 2.713 & 0.095 & 2.172 & 0.463 & 1.744 \\
\hline & {$[0.064]^{* *}$} & {$[1.792]$} & {$[1.526]$} & {$[1.139]^{* *}$} & {$[0.070]$} & {$[1.783]$} & {$[1.556]$} & [1.109] \\
\hline \# People 0-5 & 0.075 & 1.357 & -1.016 & 2.204 & 0.109 & 2.772 & 0.005 & 2.82 \\
\hline & {$[0.044]^{*}$} & {$[1.400]$} & {$[0.965]$} & {$[1.119]^{* *}$} & {$[0.048]^{* *}$} & {$[1.294]^{* *}$} & {$[1.134]$} & {$[0.765]^{* *}$} \\
\hline \# People 6-15 & -0.029 & -1.135 & 0.188 & -1.242 & -0.049 & 0.102 & 0.434 & -0.273 \\
\hline & {$[0.035]$} & {$[1.020]$} & {$[0.755]$} & {$[0.678]^{*}$} & {$[0.035]$} & {$[0.876]$} & {$[0.675]$} & {$[0.516]$} \\
\hline \# People 16-24 & 0.05 & 1.502 & 1.355 & 0.12 & -0.01 & 0.216 & 0.542 & -0.34 \\
\hline & {$[0.036]$} & [0.983] & {$[0.806]^{*}$} & [0.641] & {$[0.036]$} & [1.045] & [0.906] & {$[0.547]$} \\
\hline \# People 25-64 & -0.052 & -4.144 & -1.601 & -2.558 & -0.071 & -1.712 & 0.425 & -2.134 \\
\hline & [0.069] & {$[2.165]^{*}$} & [1.544] & {$[1.534]^{*}$} & {$[0.073]$} & [1.991] & [1.908] & {$[1.027]^{* *}$} \\
\hline \# People 65+ & -0.174 & -2.972 & 0.456 & -3.408 & -0.121 & -2.712 & -0.521 & -2.253 \\
\hline & {$[0.070]^{* *}$} & [1.966] & [1.692] & {$[1.257]^{* *}$} & {$[0.080]$} & {$[2.021]$} & {$[1.772]$} & {$[1.266]^{*}$} \\
\hline Observations & 4602 & 4597 & 4617 & 4600 & 4868 & 4860 & 4886 & 4864 \\
\hline R-squared & 0.42 & 0.47 & 0.39 & 0.26 & 0.38 & 0.41 & 0.34 & 0.23 \\
\hline
\end{tabular}

Columns 1-4 are separate regressions for girls. Columns 5-8 are separate regressions for boys. See notes to table 4 for other notes about the

regressions. Robust standard errors in brackets are corrected for psu-time clustering. * significant at $10 \%$. $* *$ Significant at $5 \%$. 
Table 7: Rice Prices and Activities of the Oldest Child

limited to children with siblings in the household

\begin{tabular}{|c|c|c|c|c|c|c|c|c|}
\hline & \multicolumn{4}{|l|}{ Girls } & \multicolumn{4}{|l|}{ Boys } \\
\hline & Participation & & \multicolumn{2}{|c|}{ Hours Worked (OLS) } & Participation & & \multicolumn{2}{|c|}{ Hours Worked (OLS) } \\
\hline & -1 & -2 & -3 & -4 & -5 & -6 & -7 & -8 \\
\hline \multicolumn{9}{|l|}{ Dependent } \\
\hline Variable: & Active & Total & Market & Household & Active & Total & Market & Household \\
\hline \multirow[t]{2}{*}{ Rice Price } & -0.264 & -7.479 & -5.206 & -2.499 & -0.183 & -3.106 & -1.183 & -1.975 \\
\hline & {$[0.086]^{* *}$} & {$[2.729]^{* *}$} & {$[1.757] * *$} & [1.707] & {$[0.084]^{* *}$} & [2.051] & [1.664] & [1.311] \\
\hline \multirow[t]{2}{*}{ RP*Oldest } & -0.009 & -1.046 & 1.231 & -2.159 & -0.148 & -3.674 & -2.053 & -1.462 \\
\hline & {$[0.081]$} & [2.622] & [2.057] & [1.832] & {$[0.071]^{* *}$} & {$[1.940]^{*}$} & [1.698] & {$[1.200]$} \\
\hline \multirow[t]{2}{*}{ Oldest } & 0.129 & 4.419 & -0.55 & 4.933 & 0.24 & 6.092 & 2.831 & 3.135 \\
\hline & {$[0.087]$} & [2.884] & [2.232] & {$[2.084]^{* *}$} & {$[0.076]^{* *}$} & {$[2.073]^{* *}$} & {$[1.780]$} & {$[1.321]^{* *}$} \\
\hline \multicolumn{2}{|c|}{ Observation 4496} & 4492 & 4510 & 4494 & 4730 & 4723 & 4749 & 4726 \\
\hline R-squared & 0.42 & 0.47 & 0.39 & 0.25 & 0.37 & 0.41 & 0.35 & 0.22 \\
\hline
\end{tabular}

See notes to table 4 for other notes about the regressions. Robust standard errors in brackets are corrected for psu-time clusterin

$*$ significant at $10 \%$. ** Significant at $5 \%$. 
Table 8: Rice Prices, Child Labor, and the Presence of Younger Siblings

limited to children with siblings in the household

\begin{tabular}{|c|c|c|c|c|c|c|c|c|}
\hline \multirow[b]{4}{*}{ Dependent Variable: } & \multicolumn{4}{|c|}{ Girls } & \multicolumn{4}{|c|}{ Boys } \\
\hline & \multicolumn{2}{|c|}{$\underline{\text { Participation }}$} & \multicolumn{2}{|c|}{ Hours Worked (OLS) } & \multicolumn{2}{|c|}{ Participation } & \multicolumn{2}{|c|}{ Hours Worked (OLS) } \\
\hline & -1 & -2 & -3 & -4 & -5 & -6 & -7 & -8 \\
\hline & Active & Total & Market & Household & Active & Total & Market & Household \\
\hline \multirow[t]{2}{*}{ Rice Price } & -0.251 & -7.227 & -3.888 & -3.59 & -0.215 & -2.829 & -1.45 & -1.276 \\
\hline & {$[0.105]^{* *}$} & {$[3.091]^{* *}$} & {$[2.019]^{*}$} & {$[2.078]^{*}$} & {$[0.098]^{* *}$} & [2.633] & {$[2.077]$} & {$[1.526]$} \\
\hline \multirow[t]{2}{*}{ RP*\# Siblings } & -0.007 & -0.219 & -0.351 & 0.148 & -0.001 & -0.423 & -0.089 & -0.376 \\
\hline & {$[0.022]$} & {$[0.680]$} & {$[0.467]$} & {$[0.479]$} & {$[0.022]$} & {$[0.640]$} & {$[0.536]$} & {$[0.324]$} \\
\hline \multirow[t]{2}{*}{ \# Siblings } & -0.005 & -0.097 & 0.378 & -0.489 & -0.002 & 0.323 & 0.189 & 0.166 \\
\hline & {$[0.023]$} & {$[0.755]$} & {$[0.496]$} & {$[0.542]$} & {$[0.025]$} & {$[0.722]$} & {$[0.589]$} & {$[0.370]$} \\
\hline Observations & 4496 & 4492 & 4510 & 4494 & 4730 & 4723 & 4749 & 4726 \\
\hline R-squared & 0.41 & 0.46 & 0.39 & 0.23 & 0.37 & 0.41 & 0.34 & 0.21 \\
\hline \multirow[t]{2}{*}{ Rice Price } & -0.254 & -6.565 & -3.647 & -3.188 & -0.223 & -2.491 & -1.144 & -1.248 \\
\hline & {$[0.104]^{* *}$} & {$[3.104]^{* *}$} & {$[2.027]^{*}$} & [2.112] & {$[0.099]^{* *}$} & {$[2.674]$} & [2.131] & {$[1.535]$} \\
\hline \multirow[t]{2}{*}{ RP*\# Siblings } & 0.003 & 0.626 & 0.061 & 0.572 & 0.016 & 0.462 & 0.453 & -0.024 \\
\hline & {$[0.025]$} & {$[0.722]$} & {$[0.524]$} & {$[0.466]$} & {$[0.026]$} & {$[0.687]$} & {$[0.558]$} & {$[0.370]$} \\
\hline \multirow[t]{2}{*}{ RP* \# younger sibs } & -0.083 & -2.853 & -1.803 & -1.045 & -0.065 & -4.178 & -3.021 & -1.224 \\
\hline & {$[0.045]^{*}$} & {$[1.528]^{*}$} & {$[1.276]$} & [0.961] & {$[0.042]$} & {$[1.137]^{* *}$} & {$[0.991]^{* *}$} & {$[0.596]^{* *}$} \\
\hline \multirow[t]{2}{*}{ RP*\# young male sibs } & 0.133 & 1.206 & 1.41 & -0.142 & 0.051 & 3.396 & 2.856 & 0.631 \\
\hline & {$[0.057]^{* *}$} & {$[1.815]$} & {$[1.663]$} & {$[1.370]$} & {$[0.054]$} & {$[1.462]^{* *}$} & {$[1.264]^{* *}$} & {$[0.783]$} \\
\hline \multirow[t]{2}{*}{ \# siblings } & -0.036 & -1.454 & -0.198 & -1.272 & -0.038 & -1.011 & -0.547 & -0.441 \\
\hline & {$[0.027]$} & {$[0.799]^{*}$} & {$[0.562]$} & {$[0.529]^{* *}$} & [0.029] & {$[0.767]$} & {$[0.614]$} & {$[0.416]$} \\
\hline \multirow[t]{2}{*}{ \# younger sibs } & 0.157 & 4.385 & 2.332 & 2.102 & 0.121 & 5.446 & 3.457 & 2.063 \\
\hline & {$[0.047]^{* *}$} & {$[1.610]^{* *}$} & {$[1.356]^{*}$} & {$[1.050]^{* *}$} & {$[0.045]^{* *}$} & {$[1.242]^{* *}$} & {$[1.089]^{* *}$} & {$[0.663]^{* *}$} \\
\hline \multirow[t]{2}{*}{ \# younger male sibs } & -0.143 & -0.905 & -1.407 & 0.401 & -0.036 & -2.925 & -2.412 & -0.6 \\
\hline & {$[0.060]^{* *}$} & [1.923] & {$[1.778]$} & [1.487] & {$[0.059]$} & {$[1.586]^{*}$} & {$[1.390]^{*}$} & {$[0.883]$} \\
\hline Observations & 4496 & 4492 & 4510 & 4494 & 4730 & 4723 & 4749 & 4726 \\
\hline R-squared & 0.43 & 0.48 & 0.39 & 0.26 & 0.38 & 0.42 & 0.35 & 0.22 \\
\hline
\end{tabular}

Top panel and bottom panel are separate regressions. See notes to table 5 for additional explanation of regressions. Robust standard errors in

brackets are corrected for psu-time clustering. * significant at $10 \%$. ** Significant at $5 \%$. 